\title{
Risky Mortgages in a DSGE Model*
}

\author{
Chiara Forlati and Luisa Lambertini \\ École Polytechnique Fédérale de Lausanne
}

This paper develops a DSGE model with housing, risky mortgages, and endogenous default. Housing investment is subject to idiosyncratic risk, and some mortgages are defaulted in equilibrium. An unanticipated increase in the standard deviation of housing investment risk produces a credit crunch where delinquencies and mortgage interest rates increase, lending is curtailed, and aggregate demand for non-durable goods falls. The economy experiences a recession as a consequence of the credit crunch. The paper compares economies that differ only in the riskiness of housing investment. Economies with lower risk are characterized by lower steady-state mortgage default rates and higher loan-to-value and leverage ratios. The macroeconomic effects of an unanticipated increase in housing investment risk are amplified in high-leverage economies. Monetary policy plays an important role in the transmission of housing investment risk, as inertial interest rate rules generate deeper output contractions.

JEL Codes: E32, E44, G01, R31.

\section{Introduction}

The global financial crisis that began in August 2007 has its roots in increased mortgage delinquencies that put financial institutions into

${ }^{*}$ We would like to thank Matteo Iacoviello, Andrew Levin, Eileen Mauskopf, Elmar Mertnes, Tomoyuki Nakajima, and the IJCB workshop participants for their comments and suggestions, and Yankai Shao for excellent research assistance. We are also grateful to seminar participants at Universidad Autonoma de Barcelona, UNIL, Claremont McKenna College, the conference on Monetary and Fiscal Policy for Macroeconomic Stability, the workshop on Heterogeneous Nations and Globalized Financial Markets, the 2010 EEA Meeting, the SNB Research Conference on Monetary Policy after the Financial Crisis, the Bank of Italy-Bank of France conference on The Future of Monetary Policy, and the Moncasca Money Workshop for useful feedback. Corresponding author: Luisa Lambertini, EPFL CDM SFI-LL, ODY 2 05, Station 5, CH-1015 Lausanne, Switzerland. E-mail: luisa.lambertini@epfl.ch. 
distress. The bursting of the housing bubble in the United States placed many borrowers in a difficult financial position, with mortgages they could not pay in the long run and larger than the value of the houses against which they were underwritten. As a result, the rate of seriously delinquent mortgages ${ }^{1}$ increased from 2 percent in the third quarter of 2006 to 10 percent by the first quarter of 2010. Banks were forced to write down several hundred billion dollars in bad mortgages. These losses, combined with a high degree of opacity surrounding mortgage-backed securities and a complicated web of interconnected obligations among financial institutions, triggered a severe liquidity crisis in the interbank market. A credit crunch followed that caused failure of several financial institutions, brought many others close to it, raised interbank rates, and drastically reduced household access to borrowing. The fall in housing prices and tightened credit conditions forced many borrowers to quickly deleverage, cutting consumption and housing investment. The turmoil that started in the mortgage market spread to the rest of the economy to spark the Great Recession.

Several factors contributed to the depth and persistence of the recent recession. We focus on one of these factors: the increase in mortgage delinquencies and its transmission to the rest of the economy. Our goal is mainly methodological: we introduce endogenous default on mortgages in a dynamic stochastic general equilibrium (DSGE) model with housing. Endogenous default arises because housing investment is subject to idiosyncratic risk, which can bring loan repayment above the housing value. The paper analyzes how aggregate shocks affect the rate of default on mortgages and how an increase in the rate of default on mortgages transmits to the rest of the economy. Driven by recent events, we focus on an unanticipated increase in mortgage risk, which we model as an unanticipated increase in the volatility of idiosyncratic housing investment risk.

Figure 1 shows the impulse responses from a four-lag VAR with seriously delinquent mortgages (DEL), real per capita consumption (CC), real per capita residential investment (IH), the four-quarter change in the log of the implicit price deflator for the non-farm

\footnotetext{
${ }^{1}$ According to the National Delinquency Survey of the Mortgage Bankers Association, seriously delinquent mortgages are those more than ninety days past due or in foreclosure.
} 


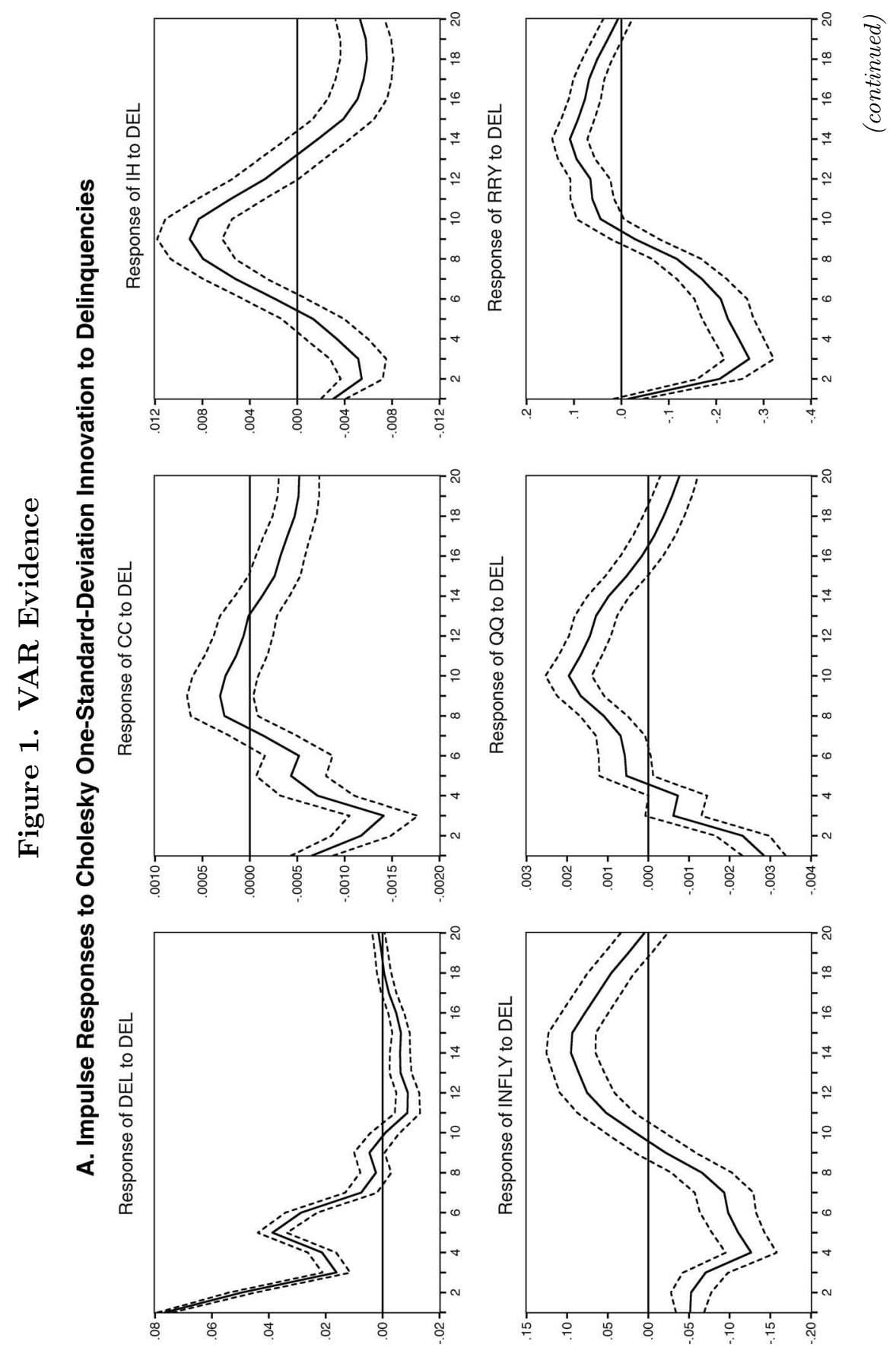



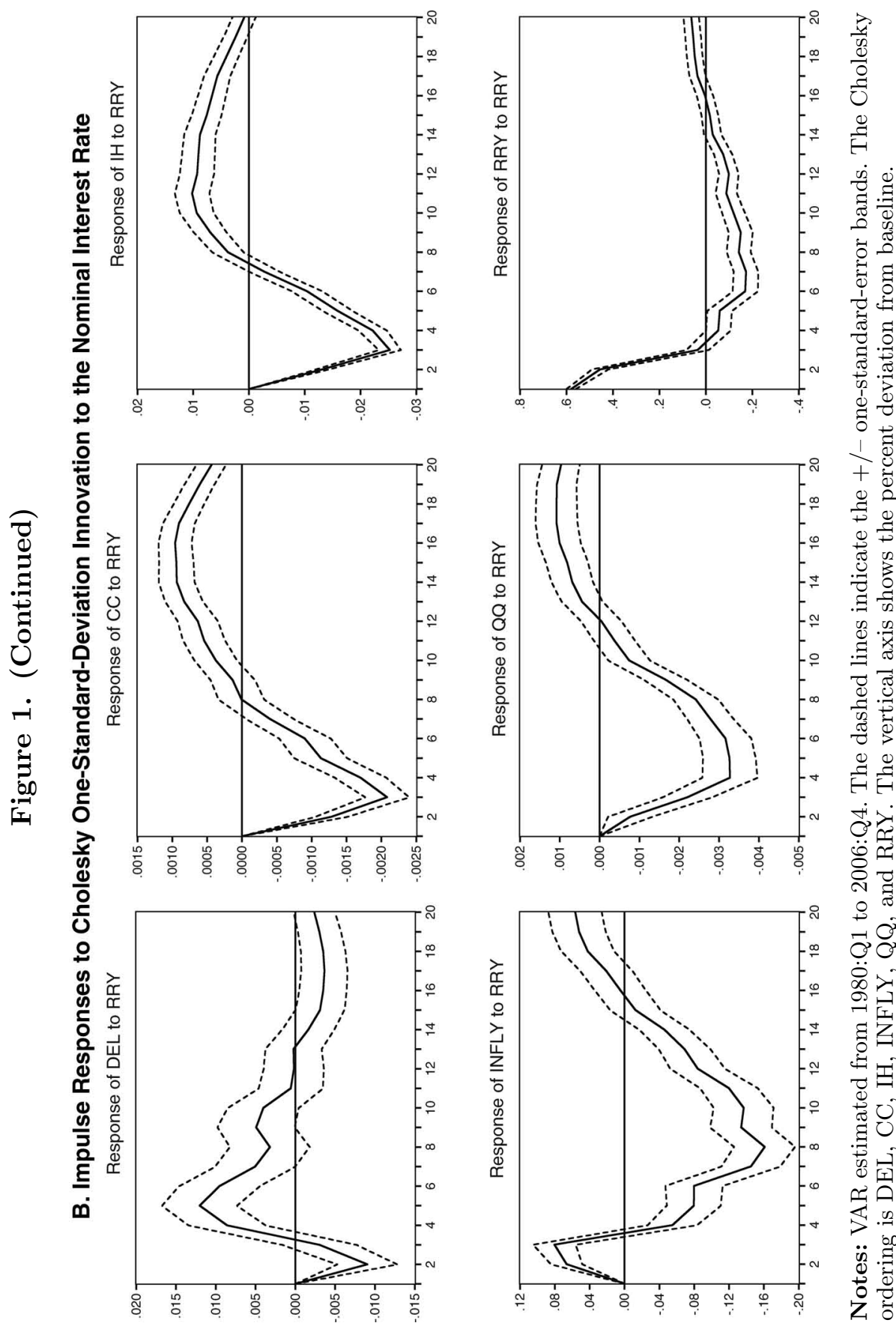

0

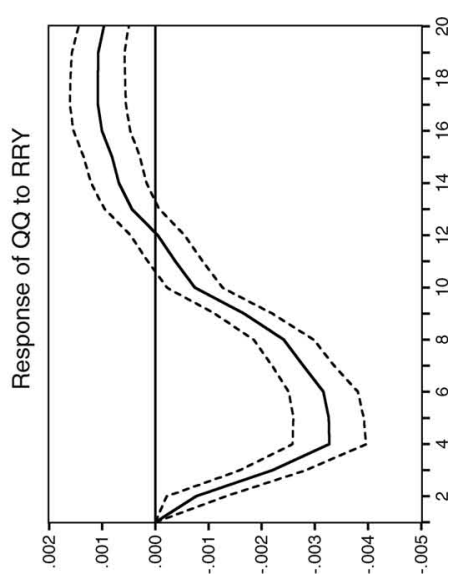

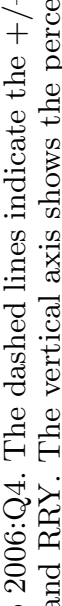

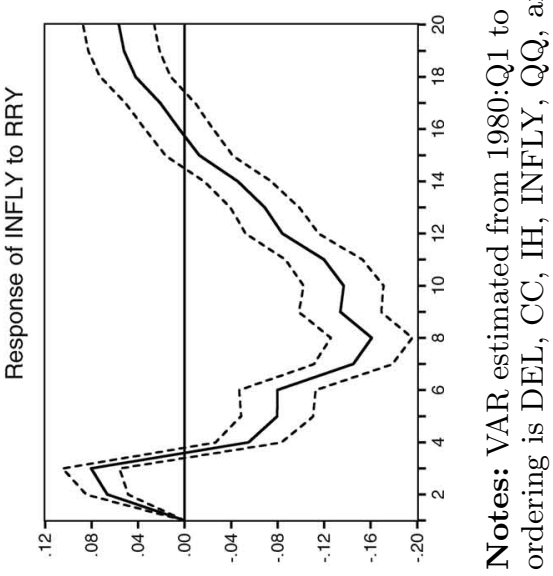


business sector (INFLY), real house prices (QQ), and the nominal short-term interest rate (RRY) from 1980:Q1 to 2006:Q4. ${ }^{2}$ All data are for the United States. The starting date for our VAR is dictated by data availability on mortgage delinquencies. On the other hand, we purposely limit our sample to 2006:Q4 to exclude the bursting of the U.S. housing bubble and the sharp increase in delinquencies experienced since the first quarter of 2007. Variables are listed in their Cholesky ordering. Delinquencies are ordered first because we allow for a shock in the mortgage market and mortgage delinquencies to affect contemporaneously all other variables. Ordering delinquencies after the other variables, and in particular after housing prices, does not change the qualitative responses to an innovation to delinquencies, although standard errors become larger. As is standard in the literature, we order the nominal short-term interest rate last. All variables are detrended using the Hodrick-Prescott filter.

Panel A of figure 1 illustrates the impulse responses of our six variables to a one-standard-deviation innovation in serious delinquencies. It suggests a significant short-run negative response of private consumption, residential investment, inflation, real house prices, and the nominal interest rate to a positive innovation to mortgage delinquencies. Residential investment and house prices, the variables connected to the housing sector, fall on impact and rebound after five quarters. The variables connected to the non-durable sector, on the other hand, experience a more persistent decline, as private consumption and inflation of non-durable goods remain below baseline for eight quarters. This evidence points to a significant transmission mechanism of shocks from the mortgage market to the rest of the economy.

Panel B of figure 1 shows the impulse responses of our six variables to a one-standard-deviation innovation in the nominal interest rate. An increase in the nominal interest rate reduces consumption and residential investment. As already pointed out in the literature, ${ }^{3}$ the output response in the durable sector - in our case, residential investment - is stronger than in the non-durable sector. Real house prices fall following an innovation to the nominal interest rate, as is

\footnotetext{
${ }^{2}$ See appendix 1 for data definition and sources.

${ }^{3}$ See Erceg and Levin (2006).
} 
consistent with the evidence in Iacoviello (2005). Mortgage delinquencies fall on impact but increase soon afterward and remain above baseline for about six quarters. Mortgage delinquencies fall in response to an innovation in residential investment (not shown in the paper but available in appendix $3^{4}$ ). Hence, mortgage delinquencies react significantly to aggregate shocks. To sum up, the VAR evidence points to the fact that mortgage delinquencies are an endogenous variable that affects and is affected by other fundamental macroeconomic variables. Our goal is to build a general equilibrium macroeconomic model that captures these relationships.

Our model features two households that differ in terms of their discount factor. Savers have a higher discount factor than Borrowers and, in equilibrium, lend to Borrowers. Preferences are specified over consumption of non-durable goods, housing services, and hours worked. Borrowers use their houses as collateral for mortgages and experience idiosyncratic housing investment shocks that are private information. Lenders (Savers) must pay a monitoring cost to observe Borrowers' realized housing return. Borrowers experiencing low realizations of the idiosyncratic shock default on their mortgages; Borrowers who repay their mortgages pay a state-contingent adjustable mortgage rate that is above the risk-free one. Hence, our model is characterized by endogenous default on mortgages and a mortgage, or external finance, premium.

We study the dynamic response to an unanticipated increase in the standard deviation of idiosyncratic risk to housing investment, which we also refer to as mortgage risk. More precisely, we assume that the standard deviation of mortgage risk follows an exogenous stochastic process and we analyze the dynamic response of our model following a positive shock to such standard deviation. This assumption captures the idea that housing investment risk is time variant. For example, the entrance in the mortgage market of subprime debtors may have increased mortgage risk, and our model can capture this increase in riskiness as an exogenous time variation in risk. Our model produces a credit crunch that generates a recession not only in the housing sector but also in the non-durable one. Mortgage

\footnotetext{
${ }^{4}$ Appendix 3 is available on the corresponding author's web site at http://cfi.epfl.ch/cms/page-40442.html.
} 
default rates as well as the mortgage premium, namely the spread between the adjustable mortgage rate and the risk-free rate, increase. Households with mortgages are particularly hurt. Borrowers experience a deterioration of their financial situation and tighter credit conditions, which force them to deleverage and cut non-durable consumption and housing investment. Aggregate non-durable consumption and total output fall. The relative price of houses falls and then rapidly rebounds. An increase in mortgage risk generates a recession, but it fails to generate a large and persistent decline in real housing prices.

We consider two economies that differ only in mortgage risk. The economy with a lower steady-state standard deviation of mortgage risk has a lower steady-state rate of default on mortgages. As a result, mortgages are larger and the economy is more leveraged. Economies with higher leverage ratios display more redistribution and more polarized responses to aggregate shocks, as the two households stand at the opposite sides of the mortgage contract. When mortgage risk increases, Borrowers are hurt more and the effects of the credit crunch are amplified. Hence, more leveraged economies suffer deeper recessions.

We analyze the dynamic response to an increase in mortgage risk under alternative specifications of the interest rate rule that governs monetary policy. More inertial rules feature less aggressive interest rate reductions in response to a mortgage risk shock that ultimately lead to deeper output contractions in the non-durable sector and in the economy. Non-inertial interest rate rules, on the other hand, generate large negative interest rate responses that boost Savers' nondurable consumption and successfully smooth out the contraction in the non-durable sector. Hence, interest rate flexibility is important in responding to a mortgage risk shock.

The rest of the paper is organized as follows. Section 2 discusses the related literature and section 3 presents the model. Section 4 presents two calibrations, benchmark and low leverage, and analyzes the difference in the steady state of the two economies. Section 5 analyzes the transmission mechanism in response to a mortgage risk shock in the benchmark and low-leverage economy, and it analyzes the role of interest rate flexibility. Section 6 analyzes the dynamic response of the model to a monetary shock. Section 7 summarizes and suggests future directions for research. 


\section{Related Literature}

A growing literature embeds durable goods in DSGE models. Barsky, House, and Kimball (2007) introduce durable goods in an otherwise standard sticky-price model and show that the pricing of durable goods plays a key role in the response to a monetary shock. More precisely, if prices of durable goods are sticky, the model behaves as if most prices are sticky. On the other hand, if prices of durable goods are flexible, the model behaves as if most prices are flexible. When durable prices are flexible, the durable goods sector shrinks in response to a monetary expansion, thereby offsetting the expansion in the non-durable goods sector and leaving GDP unchanged. Erceg and Levin (2006) use VAR evidence to document positive sectoral co-movement as well as higher sensitivity of the durable goods sector (relative to the non-durable one) to the nominal interest rate in response to a monetary shock. To match this empirical evidence with the model impulse responses, Erceg and Levin (2006) assume wage stickiness and the same degree of price stickiness in the durable and non-durable sector. They show that social welfare depends on the variances of sectoral output gaps and on the dispersion of prices and wages in each sector. Hence, optimal monetary policy is well approximated by a simple rule that targets a weighted average of wage and price inflation. Carlstrom and Fuerst (2006) underline the existence of a co-movement puzzle following a monetary policy shock since negative sectoral co-movement and price stickiness in the durable sector are both counterfactual. They suggest introducing sticky wages and adjustment costs in the durable sector to bring the model predictions closer to the empirical findings.

A second group of contributions incorporates financial frictions à la Kiyotaki and Moore (1997) into a model with housing as a durable good, sticky prices, and two households with different discount factors. To ensure the existence of an equilibrium, Iacoviello (2005) assumes an exogenous borrowing constraint according to which impatient agents can borrow a fraction of the expected discounted future value of their houses. Using housing as collateral generates a financial accelerator in response to demand shocks that helps reconcile the VAR evidence with the impulse responses of the model. Iacoviello and Neri (2010) extend the work of Iacoviello (2005) and 
write a DSGE model with housing that is estimated using U.S. data for the period 1965:Q1 to 2006:Q3. Calza, Monacelli, and Stracca (2009) analyze how the transmission mechanism of monetary shocks in a housing model à la Iacoviello is affected by alternative values of the downpayment rate and the interest rate mortgage structure. Monacelli (2009) shows that a model where housing is used as collateral features co-movement in response to a monetary shock, provided the durable sector displays some degree of price stickiness.

Our housing model draws a number of features from these contributions. As in Iacoviello (2005) and Iacoviello and Neri (2010), we build a model with two household groups and housing as a durable good. In our model, however, some loans are not repaid. In fact, the novelty of our paper is to introduce idiosyncratic risk in housing investment and the possibility for loans to be defaulted on, which results in an endogenous borrowing constraint similar to that for entrepreneurs in Bernanke, Gertler, and Gilchrist (1999).

The literature on the financial accelerator is vast. Starting with Carlstrom and Fuerst (1997) and Bernanke, Gertler, and Gilchrist (1999), many papers have introduced this credit friction in DSGE models to analyze its role on the transmission of shocks. We do not present an exhaustive review of the financial accelerator literature here, but rather focus on some recent applications that are closer to our study. Aoki, Proudman, and Vlieghe (2004) model risk-neutral homeowners that buy houses and rent them to a representative household. The homeowners' problem is akin to that of entrepreneurs in Bernanke, Gertler, and Gilchrist (1999). Households are either consumption smoothers or rule-of-thumb consumers who consume their labor income and transfers from homeowners. Aoki, Proudman, and Vlieghe (2004) analyze the effects of monetary policy shocks when transactions costs for borrowing against housing equity fall. In our model, mortgage default and the associated loss of housing stock affect risk-averse, borrowing-constrained consumers rather than risk-neutral homeowners, so that the transmission mechanism is different. Moreover, our focus is on an unanticipated increase in idiosyncratic mortgage risk and its effects on the macroeconomy.

Christiano, Motto, and Rostagno (2009) augment a standard monetary DSGE model to include financial markets and a financial accelerator and fit the model to European and U.S. data. They 
analyze an increase in the standard deviation of idiosyncratic risk in loans to entrepreneurs. In our setting, idiosyncratic risk is in mortgage loans. Cohen-Cole and Martinez-Garcia (2008) consider a model with a financial accelerator as in Bernanke, Gertler, and Gilchrist (1999) and introduce systemic risk, namely an aggregate variable that affects the variance of idiosyncratic risk, and banking regulation. Similarly, Faia and Monacelli (2007) consider systemic risk as a correlation between the mean of the idiosyncratic risk and the aggregate shock. We do not consider systemic risk but allow for time variation in the standard deviation of the distribution of idiosyncratic housing investment risk.

Some recent papers examine the effects of different shocks to loan repayment. Dellas, Diba, and Loisel (2010) add a banking sector to an otherwise standard New Keynesian model and consider some financial shocks, among them an increase in the exogenous rate of default of firms on bank loans. They argue that price stability is all that matters for monetary policy, even when financial factors are present. Our work differs from Dellas, Diba, and Loisel (2010) in a number of ways. Our model features a housing sector but no financial sector; moreover, default on loans is endogenous in our model while it is exogenous in Dellas, Diba, and Loisel (2010). Iacoviello (2010) introduces the banking sector in a model with housing and studies an exogenous shock to how much borrowers repay. This repayment shock is exogenous and different from default because borrowers do not lose their houses following a negative repayment shock.

\section{The Model}

Our starting point is a model with patient and impatient households that consume non-durable goods and housing services and work. Many features of our model draw from the housing model of Iacoviello (2005), Monacelli (2009), and Iacoviello and Neri (2010). Our focus, however, is on the mortgage contract and on how its features matter for the transmission of shocks. We do not rely on an exogenous borrowing constraint, but rather derive it endogenously from the lenders' participation constraint after explicitly introducing idiosyncratic risk and default. 


\subsection{Households}

The economy is populated by a continuum of households distributed over the $[0,1]$ interval. A fraction $\psi$ of identical households has discount factor $\beta$ while the remaining fraction $1-\psi$ has discount factor $\gamma>\beta$. We are going to refer to the households with the lower discount factor as Borrowers, as these households value current consumption relatively more than the other agents and therefore want to borrow. We are going to refer to households with the higher discount factor as Savers.

\subsubsection{Borrowers}

Borrowers have a lifetime utility function given by

$$
\sum_{t=0}^{\infty} \beta^{t} E_{0}\left\{U\left(X_{t}, N_{C, t}, N_{H, t}\right)\right\}, \quad 0<\beta<1,
$$

where $N_{C, t}$ is hours worked in the non-durable sector, $N_{H, t}$ is hours worked in the housing sector, and $X_{t}$ is an index of non-durable and durable consumption services defined as

$$
X_{t} \equiv\left[(1-\alpha)^{\frac{1}{\eta}} C_{t}^{\frac{\eta-1}{\eta}}+\alpha^{\frac{1}{\eta}} H_{t+1} \frac{\eta-1}{\eta}\right]^{\frac{\eta}{\eta-1}},
$$

where $C_{t}$ denotes consumption of non-durable goods, $H_{t+1}$ denotes consumption of housing services, $\alpha$ is the share of housing in the consumption index, and $\eta \geq 0$ is the elasticity of substitution between housing and non-durable services. We assume that housing services in period $t$ are equal to the housing stock chosen at the beginning of period $t, H_{t+1}$. Assuming that services are a fraction of the stock is not going to change qualitatively our results.

We assume the following period utility function:

$$
U\left(X_{t}, N_{t}\right) \equiv \ln X_{t}-\frac{\nu}{1+\varphi}\left[N_{C, t}^{1+\xi}+N_{H, t}^{1+\xi}\right]^{\frac{1+\varphi}{1+\xi}}, \quad \varphi, \xi \geq 0 .
$$

Our specification for the disutility of labor follows Iacoviello and Neri (2010) in allowing that hours in the non-durable and housing sector are imperfect substitutes, as is consistent with the evidence found by Horvath (2000). For $\xi=0$, hours in the non-durable and 
housing sector are perfect substitutes. On the other hand, positive values of $\xi$ result in wages not being equalized in the two sectors and the substitution of hours across sectors in response to wage differentials being reduced. The parameter $\varphi$ is the inverse of the Frisch labor supply elasticity.

Borrowers are subject to the sequence of budget constraints:

$$
\begin{aligned}
& P_{C, t} C_{t}+P_{H, t} H_{t+1}+\left[1-F_{t}\left(\bar{\omega}_{t}\right)\right]\left(1+R_{Z, t}\right) L_{t} \\
& \quad=L_{t+1}+W_{C, t} N_{C, t}+W_{H, t} N_{H, t}+(1-\delta)\left[1-G_{t}\left(\bar{\omega}_{t}\right)\right] P_{H, t} H_{t},
\end{aligned}
$$

where $P_{C, t}$ is the price of non-durable goods, $P_{H, t}$ is the price of housing, and $L_{t+1}$ are the loans taken from Savers at $t$ to be repaid in period $t+1$. $R_{Z, t}$ is the state-contingent interest rate that nondefaulting Borrowers pay at $t$ on the loans $L_{t}$ taken at time $t-1$, and $W_{j, t}$ is the nominal wage in sector $j=C, H$. In equilibrium, some loans are going to be defaulted on. The term $G_{t}\left(\bar{\omega}_{t}\right)$ represents the fraction of Borrowers' housing stock that has been seized by Savers as a consequence of default in period $t ;\left[1-F_{t}\left(\bar{\omega}_{t}\right)\right]$ is the fraction of loans that is repaid to lenders. We explicitly derive and explain these two terms later. The housing stock depreciates at the rate $\delta$. Each household decides non-durable good consumption, housing investment (and consumption), working hours in the two sectors, and loans.

It is worth noticing at this point that the state-contingent interest rate $R_{Z, t}$ is determined at time $t$ after the realization of shocks and in order to satisfy the participation constraint of lenders, which we explain in detail later. Hence, our mortgage contract is characterized by adjustable interest rates.

Each household consists of many members. The household decides total housing investment $H_{t+1}$ and the state-contingent mortgage rates to be paid next period on the contracts signed this period. The household then assigns equal resources to each $i$-th member to purchase the housing stock $H_{t+1}^{i}$, where $\int_{i} H_{t+1}^{i} d i=H_{t+1}$. The $i$-th member finalizes the mortgage contract connected to the housing stock $H_{t+1}^{i}$ following the instructions of the household and manages his housing stock. All members are ex ante identical. After the mortgage contract is finalized, the $i$-th household member experiences an idiosyncratic shock $\omega_{t+1}^{i}$ such that his ex post housing value 
is $\omega_{t+1}^{i} P_{H, t+1} H_{t+1}^{i}$. This assumption captures the idea that housing investment is risky. An alternative interpretation is that housing prices are subject to idiosyncratic risk so that the ex post price of the housing stock $i$ is equal to $\omega_{t+1}^{i} P_{H, t+1}$. This price risk could capture the fact that housing prices display geographical variation. The random variable $\omega_{t+1}^{i}$ is i.i.d. across members of the same household and log-normally distributed with a cumulative distribution function $F_{t+1}\left(\omega_{t+1}^{i}\right)$, which obeys standard regularity conditions. ${ }^{5}$ The mean and variance of $\ln \omega_{t+1}^{i}$ are chosen so that $E_{t}\left(\omega_{t+1}^{i}\right)=1$ at all times. This implies that while there is idiosyncratic risk at the household-member level, there is no risk at the household level and $E_{t}\left(\omega_{t+1}^{i} H_{t+1}^{i}\right)=H_{t+1}$. We are going to assume that housing investment riskiness can change over time, namely that the standard deviation $\sigma_{\omega, t}$ of $\ln \omega_{t}^{i}$ is subject to an exogenous shock and displays time variation. The random variable $\omega_{t+1}^{i}$ is observed by the $i$-th member and the household but can only be observed by lenders after paying a monitoring cost.

After idiosyncratic shocks are realized, the household member decides whether to repay the mortgage or to default. Loans connected to housing stocks that experienced high realizations of the idiosyncratic shock $\omega_{t+1}^{i}$ are repaid, while loans connected to housing stocks with low realizations are defaulted on. Let $\bar{\omega}_{t+1}$ be the threshold value of the idiosyncratic shock for which the member is willing to repay the loan at the contractual rate $R_{Z, t+1}$, namely

$$
\bar{\omega}_{t+1}(1-\delta) P_{H, t+1} H_{t+1}=\left(1+R_{Z, t+1}\right) L_{t+1} .
$$

Loans connected to $\omega_{t+1}^{i} \in\left[\bar{\omega}_{t+1}, \infty\right]$ are repaid and Borrowers pay $\left(1+R_{Z, t+1}\right) L_{t+1}$. On the other hand, loans connected to $\omega_{t+1}^{i} \in\left[0, \bar{\omega}_{t+1}\right)$ are defaulted on. Lenders pay a monitoring cost to assess and seize the collateral connected to the defaulted loan. It is the presence of monitoring that induces Borrowers to truthfully

${ }^{5}$ The c.d.f. is continuous, at least once-differentiable, and it satisfies

$$
\frac{\partial \omega h(\omega)}{\partial \omega}>0
$$

where $h(\omega)$ is the hazard rate. 
reveal their idiosyncratic shock and justifies the incentive compatibility constraint (5). ${ }^{6}$ The household members that default on their mortgages lose their housing stocks.

Mortgages are non-recourse in our model - that is to say, mortgages are secured by the pledge of collateral (the house), and the lender's recovery is strictly limited to the collateral. Defaulting Borrowers are not personally liable for the difference between the loan and the collateral value. Some comments are in order. This is a natural assumption in our model because housing is the only asset held by Borrowers. In addition to this, non-recourse debt is broadly applicable to most U.S. states, especially those that experienced soaring mortgage delinquencies, and the focus of our paper is on the United States. At last, non-recourse debt captures the reality of subprime mortgages, which were at the heart of the recent financial crisis.

In Bernanke, Gertler, and Gilchrist (1999) the monitoring cost is equal to a fraction of the realized gross payoff to the defaulting firm's capital. We follow Bernanke, Gertler, and Gilchrist (1999) and assume that the monitoring cost in our model is equal to the fraction $\mu$ of the housing value, $\mu \omega_{t+1}^{i} P_{H, t} H_{t+1}$. This assumption has two important implications. The first implication is that the foreclosure cost is proportional to the value of the house under foreclosure. The second implication is that mortgage default causes a decline in the housing stock and services. The second implication plays an important role in our results. We discuss its relevance as well as an alternative assumption regarding monitoring costs in the concluding section.

Regarding the defaulting household members, we follow the literature on matching and assume there is perfect insurance among household members so that consumption of non-durable goods and housing services are ex post equal across all members of the Borrower household. Hence, Borrower household members are ex post identical.

Following Bernanke, Gertler, and Gilchrist (1999), we consider a one-period mortgage contract that guarantees lenders a predetermined rate of return on their total loans. At time $t$ Savers make total loans $L_{t+1}$ to Borrowers and demand the gross rate of return

\footnotetext{
${ }^{6}$ See the seminal work of Townsend (1979).
} 
$1+R_{L, t}$. This rate of return is predetermined at $t$ and non-state contingent. Hence, the time $t$ participation constraint of lenders is given by

$$
\begin{aligned}
\left(1+R_{L, t}\right) L_{t+1}= & \int_{0}^{\bar{\omega}_{t+1}} \omega_{t+1}(1-\mu)(1-\delta) P_{H, t+1} H_{t+1} f_{t+1}(\omega) d \omega \\
& +\int_{\bar{\omega}_{t+1}}^{\infty}\left(1+R_{Z, t+1}\right) L_{t+1} f_{t+1}(\omega) d \omega
\end{aligned}
$$

where $f_{t}(\omega)$ is the probability density function of $\omega$, which is time variant because it is subject to an exogenous shock to its standard deviation. The return on total loans is equal to the housing stock net of monitoring costs and depreciation of defaulting Borrower members (the first term on the right-hand side of (6)) and the repayment by non-defaulting members (the second term on the right-hand side of (6)). After idiosyncratic and aggregate shocks have realized, the threshold value $\bar{\omega}_{t+1}$ and the state-contingent mortgage rate $R_{Z, t+1}$ are determined so as to satisfy the participation constraint above. Notice that the participation constraint holds state by state and not in expected terms. In other words, an aggregate state that raises $\bar{\omega}_{t+1}$ and the rate of default on mortgages generates an increase in the adjustable rate $R_{Z, t+1}$ paid by non-defaulting members in order to satisfy the participation constraint (6) in that state. This implies that periods characterized by high mortgage default rates are also accompanied by high mortgage interest rates in our model.

We use one-period debt contracts as in Bernanke, Gertler, and Gilchrist (1999) for tractability reasons. In reality, conventional U.S. mortgages typically have a fixed thirty-year term and about 70 percent of mortgages have fixed rates, even though this percentage has changed in recent years. Moreover, subprime mortgages with nontraditional ARM features were at the heart of the recent crisis. Our model does not consider these alternative mortgage instruments and therefore cannot capture their role at the onset of the crisis. Nevertheless, our general equilibrium model captures the effect of a fall in housing prices on mortgage default rates and its transmission to the rest of the economy.

We simplify the Borrower problem as follows. Let

$$
G_{t+1}\left(\bar{\omega}_{t+1}\right) \equiv \int_{0}^{\bar{\omega}_{t+1}} \omega_{t+1} f_{t+1}(\omega) d \omega
$$


be the expected value of the idiosyncratic shock conditional on the shock being less than or equal to the threshold value $\bar{\omega}_{t+1}$, multiplied by the probability of default, and let

$$
\Gamma_{t+1}\left(\bar{\omega}_{t+1}\right) \equiv \bar{\omega}_{t+1} \int_{\bar{\omega}_{t+1}}^{\infty} f_{t+1}(\omega) d \omega+G_{t+1}\left(\bar{\omega}_{t+1}\right)
$$

be the expected share of housing value, gross of monitoring costs, that goes to lenders. Then the participation constraint can be written more compactly as

$$
\left(1+R_{L, t}\right) l_{t+1}=\left[\Gamma_{t+1}\left(\bar{\omega}_{t+1}\right)-\mu G_{t+1}\left(\bar{\omega}_{t+1}\right)\right](1-\delta) p_{H, t+1} \pi_{C, t+1} H_{t+1},
$$

where $p_{H, t+1}$ is the relative price of houses in terms of non-durable consumption and $l_{t+1}$ are real loans, namely $L_{t+1} / P_{C, t}$. The loanto-value ratio is

$$
\Gamma_{t+1}\left(\bar{\omega}_{t+1}\right)-\mu G_{t+1}\left(\bar{\omega}_{t+1}\right)
$$

and it measures the size of the loan (principal plus interests) as a fraction of the net housing value. The loan-to-value ratio also measures the net share of the housing value that goes to the lender for repayment.

Following the decision to default at time $t+1$, Borrowers are left with the following stock of housing:

$$
\begin{aligned}
\int_{\bar{\omega}_{t+1}}^{\infty} \omega_{t+1}(1-\delta) P_{H, t} H_{t+1} f_{t+1}(\omega) d \omega & \\
= & {\left[1-G_{t+1}\left(\bar{\omega}_{t+1}\right)\right](1-\delta) P_{H, t} H_{t+1} }
\end{aligned}
$$

where the second equality makes use of the fact that $E_{t}\left(\omega_{t+1}\right)=1$. This is the expression used in the Borrowers budget constraint (4).

Using the relationship between $\bar{\omega}_{t+1}$ and $R_{Z, t+1}$ in (5) we can eliminate $R_{Z, t}$ from the Borrowers budget constraint and rewrite it in real terms as

$$
\begin{aligned}
& C_{t}+p_{H, t} H_{t+1}+\left(1+R_{L, t-1}\right) \frac{l_{t}}{\pi_{C, t}} \\
& =l_{t+1}+(1-\delta)\left[1-\mu G_{t}\left(\bar{\omega}_{t}\right)\right] p_{H, t} H_{t}+w_{C, t} N_{C, t}+w_{H, t} N_{H, t},
\end{aligned}
$$


where $\pi_{C, t}$ is non-durable-good inflation and $w_{C, t}, w_{H, t}$ are real wages in the $C$ and $H$ sector, respectively, in terms of $P_{C, t}$. Borrowers maximize (1) subject to the budget constraint (12) and the participation constraint (9) with respect to the variables $C_{t}, H_{t+1}, N_{C, t}, N_{H, t}, l_{t+1}, \bar{\omega}_{t+1}$. The respective first-order conditions are

$$
\begin{gathered}
U_{C, t}-\lambda_{B C, t}=0, \\
U_{H, t+1}-\lambda_{B C, t} p_{H, t}+\beta(1-\delta) E_{t}\left\{\left[1-\mu G_{t+1}\left(\bar{\omega}_{t+1}\right)\right] p_{H, t+1} \lambda_{B C, t+1}\right. \\
\left.+\lambda_{P C, t+1} p_{H, t+1} \pi_{C, t+1}\left[\Gamma_{t+1}\left(\bar{\omega}_{t+1}\right)-\mu G_{t+1}\left(\bar{\omega}_{t+1}\right)\right]\right\}=0, \\
U_{N_{j}, t}+\lambda_{B C, t} w_{j, t}=0, \quad j \in\{C, H\} \\
\lambda_{B C, t}-\left(1+R_{L, t}\right) E_{t}\left[\lambda_{P C, t+1}+\beta \frac{\lambda_{B C, t+1}}{\pi_{C, t+1}}\right]=0, \\
-\beta \lambda_{B C, t+1} \mu G_{t+1}^{\prime}\left(\bar{\omega}_{t+1}\right)+\lambda_{P C, t+1} \pi_{C, t+1}\left[\Gamma_{t+1}^{\prime}\left(\bar{\omega}_{t+1}\right)\right. \\
\left.-\mu G_{t+1}^{\prime}\left(\bar{\omega}_{t+1}\right)\right]=0,
\end{gathered}
$$

where $\lambda_{B C, t}$ is the Lagrangian multiplier on Borrowers budget constraint (12) and $\lambda_{P C, t+1}$ is the Lagrangian multiplier on the participation constraint (9). Notice that the first-order condition with respect to $\bar{\omega}_{t+1}$ is state by state and not in expected terms.

\subsubsection{Savers}

We denote Savers' variables with a . Savers maximize lifetime utility

$$
\max \sum_{t=0}^{\infty} \gamma^{t} E_{0}\left\{U\left(\widetilde{X}_{t}, \widetilde{N}_{C, t}, \widetilde{N}_{H, t}\right)\right\}, \quad 0<\beta<\gamma<1,
$$

where $\widetilde{X}_{t}$ is defined similarly to $(2)$. We assume the same utility function for Savers as for Borrowers. Savers maximize lifetime utility subject to the sequence of budget constraints:

$$
\begin{array}{r}
\widetilde{C}_{t}+p_{H, t} \widetilde{H}_{t+1}+\widetilde{l}_{t+1}=(1-\delta) p_{H, t} \widetilde{H}_{t}+\left(1+R_{L, t-1}\right) \frac{\widetilde{l}_{t}}{\pi_{C, t}} \\
+\widetilde{w}_{C, t} \widetilde{N}_{C, t}+\widetilde{w}_{H, t} \widetilde{N}_{H, t}+\widetilde{\Delta}_{t},
\end{array}
$$


where $\widetilde{\Delta}_{t}$ are profits in the intermediate goods sector, which are taken as given.

Savers maximize (18) subject to the budget constraint (19) with respect to $\widetilde{C}_{t}, \widetilde{H}_{t+1}, \widetilde{N}_{C, t}, \widetilde{N}_{H, t}$, and $\widetilde{l}_{t+1}$. The first-order conditions, respectively, are

$$
\begin{gathered}
U_{\widetilde{C}, t}-\widetilde{\lambda}_{B C, t}=0, \\
U_{\widetilde{H}, t+1}-\widetilde{\lambda}_{B C, t} p_{H, t}+\gamma(1-\delta) E_{t}\left[\widetilde{\lambda}_{B C, t+1} p_{H, t+1}\right]=0, \\
U_{\widetilde{N}_{j}, t}+\widetilde{\lambda}_{B C, t} \widetilde{w}_{j, t}=0, \quad j \in\{C, H\}, \\
-\widetilde{\lambda}_{B C, t}+\gamma\left(1+R_{L, t}\right) E_{t}\left[\frac{\widetilde{\lambda}_{B C, t+1}}{\pi_{C, t+1}}\right]=0,
\end{gathered}
$$

where $\widetilde{\lambda}_{B C, t}$ is the Lagrangian multiplier on Savers budget constraint (19).

\subsection{Firms and Technology}

Both the non-durable $C$ and the housing $H$ sector have intermediate and final goods producers.

\subsubsection{Final Goods Producers}

Final goods producers are perfectly competitive and produce $Y_{j, t}, j=C, H$. The technology in the $j$-th final goods sector is given by

$$
Y_{j, t}=\left(\int_{0}^{1} Y_{j, t}(i)^{\frac{\varepsilon_{j}-1}{\varepsilon_{j}}} d i\right)^{\frac{\varepsilon_{j}}{\varepsilon_{j}-1}},
$$

where $\varepsilon_{j}>1$ is the elasticity of substitution among intermediate goods in sector $j$. Standard profit maximization implies that the demand for intermediate good $i$ is given by

$$
Y_{j, t}(i)=\left(\frac{P_{j, t}(i)}{P_{j, t}}\right)^{-\varepsilon_{j}} Y_{j, t}, \forall i,
$$

where the price index is

$$
P_{j, t}=\left(\int_{0}^{1} P_{j, t}(i)^{1-\varepsilon_{j}} d i\right)^{\frac{1}{1-\varepsilon_{j}}} .
$$




\subsubsection{Intermediate Goods Sectors}

There are two intermediate goods sectors $j \in\{C, H\}$, and in each intermediate sector there is a continuum of firms, each producing a differentiated good $i \in[0,1]$. These firms are monopolistically competitive. We assume that intermediate goods firms readjust their price according to a Calvo-type mechanism. Hence, in any given period, a firm in sector $j$ may reset its price with probability $1-\theta_{j}$.

Intermediate goods firm $i$ produces according to the following production function:

$$
Y_{j, t}(i)=A_{j, t}\left[\zeta^{\frac{1}{\varsigma}} N_{j, t}(i)^{\frac{\varsigma-1}{\varsigma}}+(1-\zeta)^{\frac{1}{\varsigma}} \widetilde{N}_{j, t}(i)^{\frac{\varsigma-1}{\varsigma}}\right]^{\frac{\varsigma}{\varsigma-1}}, \quad j \in\{C, H\},
$$

where $A_{j, t}$ is the stochastic level of technology in sector $j$ and $N_{j, t}(i)$ and $\widetilde{N}_{j, t}(i)$ are the two labor types supplied, respectively, by Borrowers and Savers. $\zeta \in(0,1)$ is the labor share of Borrowers in the production function and $\varsigma>0$ is the elasticity of substitution across labor inputs. When $\varsigma$ goes to infinity, labor inputs become perfect substitutes. For simplicity these two parameters are assumed to be equal across sectors.

A firm $i$ reoptimizing in period $t$ chooses labor and its nominal price $P_{j, t}^{*}(i)$ so as to maximize the expected discount sum of nominal profits over the period during which its price remains unchanged. Thus, the maximization problem for firm $i$ is given by

$$
\begin{aligned}
& \max _{P_{j, t}^{*}(i), N_{j, t+k \mid t}(i), \widetilde{N}_{j, t+k \mid t}(i)} E_{t}\left\{\sum _ { k = 0 } ^ { \infty } \theta _ { j } ^ { k } \Lambda _ { t , t + k } \left[P_{j, t}^{*}(i) Y_{j, t+k \mid t}(i)\right.\right. \\
& -W_{j, t+k} N_{j, t+k \mid t}(i)-\widetilde{W}_{j, t+k} \widetilde{N}_{j, t+k \mid t}(i) \\
& +m c_{j, t+k \mid t}(i) P_{j, t+k}\left[A _ { j , t + k } \left[\zeta^{\frac{1}{\varsigma}} N_{j, t+k \mid t}(i)^{\frac{\varsigma-1}{\varsigma}}\right.\right. \\
& \left.\left.\left.\left.+(1-\zeta)^{\frac{1}{\varsigma}} \widetilde{N}_{j, t+k \mid t}(i)^{\frac{\varsigma-1}{\varsigma}}\right]^{\frac{\varsigma}{\varsigma-1}}-Y_{j, t+k \mid t}(i)\right]\right]\right\},
\end{aligned}
$$

where $Y_{j, t+k \mid t}(i)$ denotes output in period $t+k$ for a firm $i$ that last changed its price in period $t$. A similar interpretation applies to $N_{j, t+k \mid t}(i)$ and $N_{j, t+k \mid t}(i) \cdot m c_{j, t+k \mid t}(i)$ is the real marginal cost of a firm $i$ that last changed its price in period $t$. 
In (27) the demand and the stochastic discount factor are, respectively, given by

$$
Y_{j, t+k \mid t}(i)=\left(\frac{P_{j, t}^{*}(i)}{P_{j, t+k}}\right)^{-\varepsilon_{j}} Y_{j, t+k}, \quad \Lambda_{t, t+k} \equiv \frac{\gamma^{k} \widetilde{\lambda}_{B C, t+k}}{\widetilde{\lambda}_{B C, t}} .
$$

The first-order conditions relative to $N_{j, t+k \mid t}(i)$ and $\widetilde{N}_{j, t+k \mid t}(i)$ are

$$
\begin{gathered}
-W_{j, t+k}+m c_{j, t+k \mid t}(i) P_{j, t+k} Y_{j, t+k \mid t}(i)^{-\frac{1}{\varsigma}} \zeta^{\frac{1}{\varsigma}} N_{j, t+k \mid t}(i)^{-\frac{1}{\varsigma}}=0, \\
-\widetilde{W}_{j, t+k}+m c_{j, t+k \mid t}(i) P_{j, t+k} Y_{j, t+k \mid t}(i)^{-\frac{1}{\varsigma}}(1-\zeta)^{\frac{1}{\varsigma}} \widetilde{N}_{j, t+k \mid t}(i)^{-\frac{1}{\varsigma}}=0,
\end{gathered}
$$

which state that the nominal marginal cost equals the ratio of the nominal wage to the marginal product of each type of labor input. By rearranging (28) and (29), we obtain

$$
m c_{j, t+k \mid t}(i)=\frac{1}{A_{j, t+k} P_{j, t+k}}\left[\zeta W_{j, t+k}^{1-\varsigma}+(1-\zeta) \widetilde{W}_{j, t+k}^{1-\varsigma}\right]^{\frac{1}{1-\varsigma}} .
$$

According to $(30), m c_{j, t+k \mid t}(i)=m c_{j, t+k}$. Marginal costs are equal across firms because wages are the same across all firms.

The first-order condition relative to the price is given by

$$
\begin{aligned}
E_{t}\left\{\sum_{k=0}^{\infty} \theta_{j}^{k} \Lambda_{t, t+k}\right. & {\left[\left(\frac{P_{j, t}^{*}(i)}{P_{j, t+k}}\right)^{\left(-\varepsilon_{j}-1\right)}\right.} \\
& \left.\left.\times Y_{j, t+k}\left(\frac{P_{j, t}^{*}(i)}{P_{j, t+k}}-\frac{\varepsilon_{j}}{\varepsilon_{j}-1} m c_{t+k}\right)\right]\right\}=0 .
\end{aligned}
$$

Finally, it can be shown ${ }^{7}$ that, under Calvo price setting, the optimal price set by reoptimizing firms is linked to the aggregate price behavior by the following condition:

$$
\left(\frac{P_{j, t}^{*}}{P_{j, t}}\right)^{\left(1-\varepsilon_{j}\right)}=\frac{1-\theta_{j} \pi_{j, t}^{\varepsilon_{j}-1}}{1-\theta_{j}}
$$

where $\pi_{j, t}$ denotes gross inflation in sector $j$.

\footnotetext{
${ }^{7}$ For a formal proof see, for instance, Woodford (2003).
} 


\subsection{Monetary Policy}

We assume that monetary policy follows a Taylor-type rule for the nominal interest rate:

$$
\frac{1+R_{L, t}}{1+R_{L}}=A_{M, t}\left[\pi_{C, t}^{\phi_{\pi}}\right]^{1-\phi_{r}}\left[\frac{1+R_{L, t-1}}{1+R_{L}}\right]^{\phi_{r}}, \quad \phi_{\pi}>1, \phi_{r}<1,
$$

where $R_{L}$ is the steady-state nominal interest rate, $\phi_{\pi}$ is the coefficient on the inflation target, $\phi_{r}$ is the coefficient on the lagged interest rate, and $A_{M, t}$ is a monetary policy shock. In our benchmark calibration, monetary policy targets inflation in the non-durable goods sector and implements interest rate smoothing.

\subsection{Market Clearing}

Equilibrium in the non-durable goods market requires that production of the final non-durable good equals aggregate demand:

$$
Y_{C, t}=\psi C_{t}+(1-\psi) \widetilde{C}_{t} .
$$

Similarly, equilibrium in the housing market requires

$$
Y_{H, t}=\psi\left\{H_{t+1}-(1-\delta)\left[1-\mu G_{t}\left(\bar{\omega}_{t}\right)\right] H_{t}\right\}+(1-\psi)\left[\widetilde{H}_{t+1}-(1-\delta) \widetilde{H}_{t}\right] .
$$

Output in the housing sector net of monitoring costs is equal to

$$
Y_{H, t}^{N}=Y_{H, t}-\psi \mu(1-\delta) G_{t}\left(\bar{\omega}_{t}\right) H_{t} .
$$

Equilibrium in the labor market requires

$$
\begin{gathered}
\int_{0}^{1} N_{j, t}(i) d i=\psi N_{j, t} \quad j \in\{C, H\}, \\
\int_{0}^{1} \widetilde{N}_{j, t}(i) d i=(1-\psi) \widetilde{N}_{j, t} \quad j \in\{C, H\},
\end{gathered}
$$

while the equilibrium in the credit market requires

$$
\psi l_{t}=(1-\psi) \tilde{l}_{t} .
$$


We define total output as

$$
Y_{t}=Y_{C, t}+p_{H, t} Y_{H, t} .
$$

Notice that our measurement of total output reflects variations in the relative price of housing. National account statistics, on the other hand, measure GDP at constant relative prices.

\subsection{Exogenous Shocks}

There are five exogenous shocks in our model. Aggregate productivity in the two sectors and the monetary policy shock evolve according to the following first-order autoregressive processes

$$
\begin{aligned}
& \ln A_{C, t}=\rho_{C} \ln A_{C, t-1}+\epsilon_{C, t}, \quad \rho_{C} \in(-1,1), \\
& \ln A_{H, t}=\rho_{H} \ln A_{H, t-1}+\epsilon_{H, t}, \quad \rho_{H} \in(-1,1), \\
& \ln A_{M, t}=\rho_{M} \ln A_{M, t-1}+\epsilon_{M, t}, \quad \rho_{M} \in(-1,1),
\end{aligned}
$$

where $\epsilon_{C}, \epsilon_{H}, \epsilon_{M}$ are i.i.d. innovations with mean zero and standard deviation $\sigma_{C}, \sigma_{H}, \sigma_{M}$, respectively, and $\rho_{C}, \rho_{H}, \rho_{M}$ are persistence parameters.

As for the idiosyncratic risk in the housing sector, we follow Bernanke, Gertler, and Gilchrist (1999) and assume that $\omega_{t}$ is distributed log-normally:

$$
\ln \omega_{t} \sim N\left(-\frac{\sigma_{\omega, t}^{2}}{2}, \sigma_{\omega, t}^{2}\right) .
$$

As stated earlier, the mean of the distribution is chosen so that $E_{t}\left(\omega_{t+1}\right)=1$. We are going to analyze the case where the standard deviation of idiosyncratic housing investment risk exogenously increases. To do this, we assume that the standard deviation of $\ln \omega_{t}$ is itself an exogenous shock subject to a first-order autoregressive process

$$
\ln \frac{\sigma_{\omega, t}}{\sigma_{\omega}}=\rho_{\sigma} \ln \frac{\sigma_{\omega, t-1}}{\sigma_{\omega}}+\epsilon_{\sigma_{\omega, t}},
$$

where $\epsilon_{\sigma_{\omega, t}}$ is an i.i.d. shock with mean zero and finite standard deviation $\sigma_{\sigma_{\omega}}$ and $\rho_{\sigma}$ is the serial correlation coefficient. This assumption 


\section{Table 1. Benchmark Calibration}

\begin{tabular}{|l|l|l|}
\hline Parameter & Value & \multicolumn{1}{c|}{ Description } \\
\hline$\gamma$ & 0.99 & Discount factor of Savers \\
$\beta$ & 0.98 & Discount factor of Borrowers \\
$\psi$ & 0.5 & Relative size of Borrower group \\
$\delta$ & 0.01 & Rate of depreciation for housing \\
$\varepsilon_{C}$ & 7.5 & Elasticity of substitution for $C$ goods \\
$\varepsilon_{H}$ & 7.5 & Elasticity of substitution for $H$ goods \\
$\varsigma$ & 3 & Elasticity of substitution across labor inputs \\
$\zeta$ & 0.5 & Share of Borrower labor in the production function \\
$\xi$ & 0.871 & Elasticity of substitution across labor types \\
$\alpha$ & 0.16 & Share of housing in consumption bundle \\
$\nu$ & 2.5 & Disutility from work \\
$\eta$ & 1 & Elasticity of substitution between $C$ and $H$ goods \\
$\varphi$ & 1 & Inverse of elasticity of labor supply \\
$\theta_{C}$ & 0.67 & Calvo probability in $C$ \\
$\theta_{H}$ & 0 & Calvo probability in $H$ \\
$\phi_{\pi}$ & 1.5 & Taylor-rule coefficient on inflation \\
$\phi_{r}$ & 0.9 & Taylor-rule coefficient on past nominal interest rate \\
$\rho_{C}$ & 0.9 & Serial correlation of productivity shocks in $C$ \\
$\rho_{H}$ & 0.9 & Serial correlation of productivity shocks in $H$ \\
$\rho_{M}$ & 0 & Serial correlation of monetary policy shocks \\
$\sigma_{\omega}$ & 0.20 & Standard deviation of idiosyncratic shocks \\
$\mu$ & 0.12 & Monitoring cost \\
\hline & &
\end{tabular}

captures the fact that housing investment is risky and this risk can change exogenously over time.

Private agents know these exogenous processes and use them to form correct expectations.

\section{Steady-State Analysis}

\subsection{Benchmark Calibration}

The parameter values for our benchmark calibration are specified in table 1. We follow Monacelli (2009) in choosing the values for the discount factors for Borrowers and Savers, the rate of depreciation for housing, and the elasticity of substitution between non-durable 
goods and housing services. The Savers' discount factor $\gamma$ is set equal to 0.99 and Borrowers' discount factor $\beta$ is set equal to 0.98. We choose an annual depreciation rate for housing of 4 percentage points, implying $\delta=0.01$. The elasticity of substitution between non-durable consumption and housing is $\eta=1$, which implies a Cobb-Douglas specification for the composite consumption index $X_{t}$.

U.S. private fixed investment in structures, residential and nonresidential, has been on average 5 percent of GDP from 1960 to 2009, while during the period 2000 to 2007 it averaged 8 percent of GDP. We set the parameter $\alpha$ that measures the share of housing in the consumption bundle equal to 0.16 , so that the housing sector represents 8 percent of total output at the steady state. The Savers' discount factor pins down the steady-state interest rate at $R_{L}=0.0101$ on a quarterly basis. This implies an annual interest rate equal of 4.1 percentage points. The inverse of the Frisch elasticity of labor supply $\varphi$ is set equal to one, as in Barsky, House, and Kimball (2007) and as typical in the macro literature. As for the parameter $\xi$ that measures the degree of substitutability between hours worked in the two sectors, we set it equal to 0.871. This is the appropriate weighted average of the $\xi$ for Borrowers and Savers estimated by Iacoviello and Neri (2010).

For the degree of price stickiness, we assume that housing prices are fully flexible and set $\theta_{H}=0$, which is in line with the empirical estimation of Iacoviello and Neri (2010) and the empirical evidence on price stickiness for durable goods. For non-durable goods, $\theta_{C}$ is set equal to 0.67 to imply that firms in the non-durable sector change their prices on average every nine months. For monetary policy, we set $\phi_{\pi}=1.5$ and $\phi_{r}=0.9$, which are standard values in the literature. The serial correlation of the monetary policy shock is $\rho_{M}=0$. We assume that the Borrower and Saver groups have equal size so that $\psi=0.5$.

For technology, we follow Calza, Monacelli, and Stracca (2009) and set the elasticity of substitution among intermediate goods $\varepsilon_{j}$ equal to 7.5 in each sector. Labor inputs are imperfect substitutes in production and the elasticity of substitution across Borrowers' and Savers' labor is $\varsigma=3$. We also assume that the share of Borrowers' labor in the production function $\zeta$ is equal to 0.5 . The serial correlation of the productivity shocks in the non-durable and housing sectors are chosen to be $\rho_{C}=0.9$ and $\rho_{H}=0.9$, respectively. 


\section{Table 2. Steady State under the Benchmark Calibration}

\begin{tabular}{|c|c|}
\hline Variable & \\
\hline $\begin{array}{l}\text { Consumption, Borrowers } \\
\text { Housing Demand, Borrowers } \\
\text { Hours Worked in } C \text { Sector, Borrowers }^{\mathrm{a}} \\
\text { Hours Worked in } H \text { Sector, Borrowers } \\
p_{H} \text { Output } H \text { /Total Output } \\
\text { Loans } \\
\text { Loan-to-Value Ratio } \\
\text { Leverage Ratio }^{\text {Default Rate on Mortgages }}{ }^{\mathrm{b}} \\
\text { External Finance Premium }^{\mathrm{b}} \\
\text { Mortgage Interest Rate }^{\mathrm{b}}\end{array}$ & $\begin{array}{r}44.28 \\
39.40 \\
54.30 \\
54.30 \\
8.09 \\
2.17 \\
59.17 \\
80.12 \\
2.34 \\
0.41 \\
4.51\end{array}$ \\
\hline \multicolumn{2}{|c|}{$\begin{array}{l}\text { Note: The leverage ratio is calculated as } l /\left(l+w_{C} N_{e}+w_{H} N_{H}\right) \text {. } \\
{ }^{a} \text { Expressed as percentage of aggregate level; e.g., Consumption, Borrowers }= \\
\psi C /(\psi C+(1-\psi) \tilde{C}) \text {. } \\
\text { b Annual, percentage points. }\end{array}$} \\
\hline
\end{tabular}

Table 2 reports the steady-state values for the benchmark calibration. The loan-to-value ratio is defined in equation (10) and the leverage ratio for Borrowers at the steady state is calculated as

$$
\text { Leverage Ratio }=\frac{l}{l+w_{C} N_{c}+w_{H} N_{H}},
$$

which measures the fraction of total expenses financed by loans, namely consumption of $C$ and $H$ plus loan repayment over loans. The leverage ratio captures the dependence of Borrowers from external funding.

We choose the standard deviation of the distribution of $\ln \omega$ at the steady state to match the pre-crisis delinquency rates. In the fourth quarter of 2006, seriously delinquent mortgages represented 2.21 percent of all mortgages. ${ }^{8}$ We set $\sigma_{\omega}=0.2$ and obtain an annual default rate of 2.34 percentage points. As for the shocks that raise the standard deviation of idiosyncratic housing investment risk, we

\footnotetext{
${ }^{8}$ See the National Delinquency Survey conducted by the Mortgage Bankers Association.
} 
believe they are persistent, but there is no previous work we can rely on. Christiano, Motto, and Rostagno (2009) estimate the persistence of the idiosyncratic productivity shock for the United States to be 0.85 . We set $\rho_{\sigma}=0.9$. The median foreclosure price for singlefamily residences, condominiums, and townhouses in California in the first half of 2006 was 12 percent lower than the median market price of homes sold within the same area without having been previously foreclosed - see Cagan (2006). Hence, we set $\mu=0.12$, and monitoring costs are 12 percent of the housing value. Interestingly, this is also the value for monitoring cost in Bernanke, Gertler, and Gilchrist (1999). At the steady state, the loan-to-value ratio in our benchmark calibration is almost 60 percentage points. This is lower than 75.7 percentage points, which is the average U.S. loan-to-value ratio between 1973 and 2008. We can raise the steady-state loanto-value ratio by reducing $\sigma_{\omega}$, the steady-state riskiness of loans; however, this is going to reduce the steady-state rate of default. For this reason, we prefer to match the delinquency rate but have a lower loan-to-value ratio than suggested by the data.

At the steady state, the quarterly mortgage rate paid by nondefaulting Borrowers is $R_{Z}=0.0111$, which corresponds to an annual rate of 4.51 percentage points. We define the external finance premium at $t$ as $R_{Z, t}-R_{L, t}$, namely the difference between the ex post state-contingent rate paid by non-defaulting household members and the risk-free interest rate, which in our setting is equivalent to the predetermined rate received by lenders on aggregate loans. ${ }^{9}$ This premium captures the additional cost that Borrowers must pay for their risky mortgages relative to risk-free borrowing. At the steady state, the external finance premium is equal to 0.41 percentage points on an annual basis. We calculate the empirical counterpart to our external finance premium as the difference between the thirty-year conventional mortgage rate ${ }^{10}$ and the interest rate on the U.S. Treasury thirty-year bonds. ${ }^{11}$ The average difference between these two annual interest rates between 1977 and 2009 was

\footnotetext{
${ }^{9}$ Our definition of external finance premium differs from that in Bernanke, Gertler, and Gilchrist (1999), where the premium is the difference between the costs of funds raised externally and the opportunity costs of funds internal to the firm.

${ }^{10}$ See the H-15 Release of the Federal Reserve Economic Data.

${ }^{11}$ See the Economic Report to the President, table B73.
} 
1.5 percentage points. This makes the finance premium of our benchmark model 1 percentage point lower than its empirical counterpart.

For our dynamic analysis, we log-linearize around the deterministic steady state. We solve the resulting linear system of rational expectation equations using standard techniques.

\subsection{Low-Leverage Calibration}

We additionally consider an economy characterized by higher idiosyncratic housing investment risk but otherwise identical to the benchmark economy described above. For this economy the steadystate standard deviation of the distribution of idiosyncratic housing investment risk is set to $\sigma_{\omega}=0.6$. All the other parameters are as in table 1. Higher idiosyncratic housing investment risk implies that more household members are in the left tail of the distribution and that the steady-state rate of default is higher. This raises the external finance premium and reduces mortgage loans, the loan-to-value ratio, and the leverage ratio relative to the benchmark economy. We label this calibration "low leverage" and compare it with the benchmark, "high-leverage" calibration.

Table 3 reports the steady-state values of some endogenous variables in the benchmark and the low-leverage economy. The last column of table 3 reports the percentage point difference between steady-state values in the benchmark and low-leverage economies. Because loans are larger when idiosyncratic housing investment risk is lower, steady-state loans are 173 percentage points higher in the benchmark economy, the loan-to-value ratio is 143 percentage points higher, and the leverage ratio is 34 percentage points higher. At the same time, the mortgage interest rate and the external finance premium are considerably lower in the benchmark economy. As a result, overall economic activity is higher in the economy with the higher leverage ratio.

\section{Credit Crunch}

\subsection{Benchmark Calibration}

This section analyzes the dynamic response of the model to an unanticipated increase in $\sigma_{\omega, t}$, the standard deviation of the distribution 


\section{Table 3. Benchmark and Low-Leverage Economies: Steady-State Comparison}

\begin{tabular}{|c|c|c|c|}
\hline Variable & Benchmark & $\begin{array}{c}\text { Low } \\
\text { Leverage }\end{array}$ & $\begin{array}{c}\% \\
\text { Difference }\end{array}$ \\
\hline Output $C$ & 0.5407 & 0.5399 & 0.15 \\
\hline Output $H$ & 0.1465 & 0.1419 & 3.24 \\
\hline Consumption, Borrowers & 0.4789 & 0.4887 & -2.01 \\
\hline Consumption, Savers & 0.6026 & 0.5912 & 1.93 \\
\hline Housing Demand, Borrowers & 11.5421 & 10.5337 & 9.57 \\
\hline Housing Demand, Savers & 17.7524 & 17.8431 & -0.51 \\
\hline $\begin{array}{l}\text { Hours Worked, Borrowers in } \\
C \text { Sector }\end{array}$ & 0.5879 & 0.5789 & 1.55 \\
\hline $\begin{array}{l}\text { Hours Worked, Borrowers in } \\
H \text { Sector }\end{array}$ & 0.1617 & 0.1549 & 4.41 \\
\hline $\begin{array}{l}\text { Hours Worked, Savers in } \\
C \text { Sector }\end{array}$ & 0.4948 & 0.5019 & -1.41 \\
\hline $\begin{array}{l}\text { Hours Worked, Savers in } \\
H \text { Sector }\end{array}$ & 0.1361 & 0.1343 & 1.37 \\
\hline Loans & 2.1747 & 0.7980 & 172.54 \\
\hline Loan-to-Value Ratio $^{a}$ & 59.17 & 24.37 & 142.80 \\
\hline Leverage Ratio $^{\mathrm{a}}$ & 80.12 & 60.01 & 33.51 \\
\hline Default Rate on Mortgages ${ }^{b}$ & 2.36 & 8.21 & -71.22 \\
\hline External Finance Premium ${ }^{\mathrm{b}}$ & 0.41 & 2.44 & -83.20 \\
\hline Mortgage Interest Rate ${ }^{\mathrm{b}}$ & 4.51 & 6.54 & -31.04 \\
\hline
\end{tabular}

of idiosyncratic housing investment risk. This increase in risk wants to capture the situation in which loans are made on the basis of an expected distribution for idiosyncratic risk, but the actual distribution turns out to be characterized by a higher standard deviation. In other words, the riskiness of mortgages changes over time and these changes may be persistent. More broadly, exogenous shocks to $\sigma_{\omega, t}$ are an admittedly reduced-form way to capture the entrance in the mortgage market of subprime, or higher risk, debtors. As shown in figure 11 in appendix 2, a mean-preserving increase in $\sigma_{\omega, t}$ implies an increase in the skewness of the distribution of $\omega_{t}$. Since the 
log-normal distribution does not take negative values, the lower tail of the distribution becomes thicker. Thus, for the same value of $\bar{\omega}_{t}$, a higher standard deviation implies a higher cumulative distribution function and therefore a higher default rate on mortgages.

From the third quarter of 2006 to the first quarter of 2010, the delinquency rate on U.S. real estate loans increased from 2.21 to 10.44 percentage points, an increase of 823 basis points. Figure 2 shows the impulse responses of six selected variables to a 40 percent increase relative to its steady-state value in the standard deviation $\sigma_{\omega, t}$ of idiosyncratic housing investment risk. The size of the shock is chosen so as to generate an increase in the default rate of about 800 points. The impulse responses to the same shock but of a larger set of variables are shown in figure 6 in appendix 2 . The default rate increases sharply and, together with it, the monitoring costs. Since the mortgage contract guarantees the risk-free interest rate to aggregate loans, the state-contingent mortgage interest rate must increase to satisfy the lenders' participation constraint, which implies an increase in the external finance premium paid by Borrowers. Our model predicts a 150-basis-point increase in the mortgage interest rate and the external finance premium.

The main effects of an increase in the default rate, the monitoring costs, and the external finance premium are the following. First, Borrowers' demand for non-durable goods falls substantially. Because of the mortgage risk shock, Borrowers' financial conditions worsen significantly. More Borrower household members default on their loans and lose their housing stock, while non-defaulting household members pay a higher mortgage interest rate. The overall effect on the budget constraint of the Borrower household is large and negative because the mortgage interest rate paid by non-defaulting household members rises enough to cover the increase in monitoring costs paid by the lenders - see the participation constraint (6). In addition to this, Borrowers experience a tightening in credit conditions due to a reduction in the loan-to-value ratio that reduces their capacity to borrow out of their housing stock. They also experience an increase in real debt via the Fisher effect. Worsening financial conditions force Borrowers to cut consumption of non-durable goods, housing investment, and loans, and to raise hours worked. Savers, on the other hand, are consumption smoothers. In response to a lower real interest rate, they reduce lending, consume more non-durable 

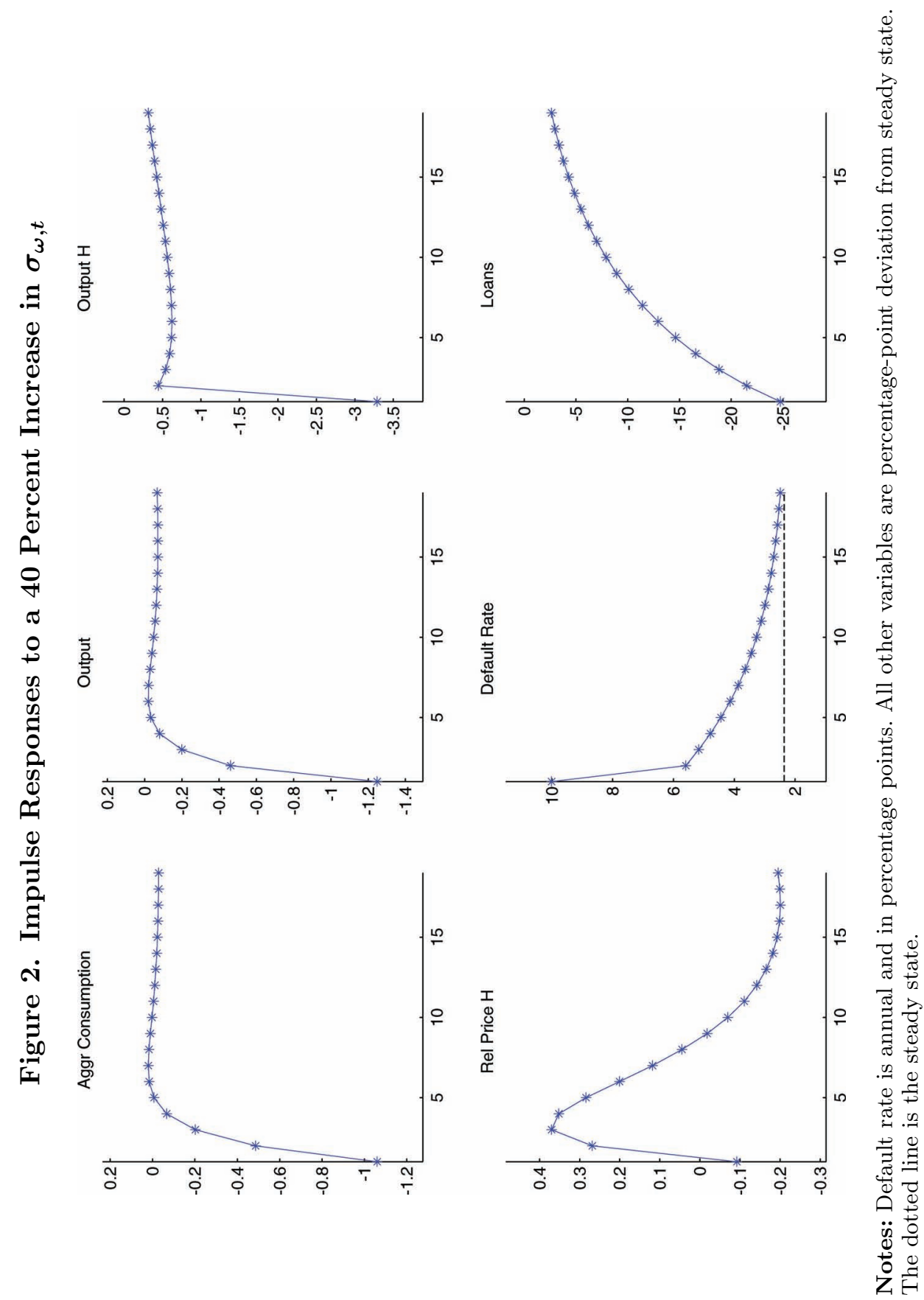
goods, and increase leisure. However, Savers' increase in consumption is small relative to the large cut by Borrowers, and aggregate consumption of non-durable goods falls.

Second, wage differentials arise in equilibrium both across sectors and across groups. Wages in the $C$ sector fall more than those in the $H$ sector for both groups, driven by the large fall in demand for non-durable goods. The resulting wage differential encourages partial switching of hours out of the non-durable into the housing sector. Imperfect substitutability of hours in the utility function prevents sectoral wage differential from disappearing. Borrowers' wages fall more than Savers'. As discussed above, Borrowers, who are credit constrained and considerably hurt by worsened financial conditions, are willing to increase labor supply. As a result, their wages fall in both sectors, but more in the non-durable one. Savers, who are consumption smoothers, increase leisure in response to the decline in the interest rate. Their labor supply drops in the non-durable sector but increases, at least on impact, in the residential one. In fact, the wage of Savers in the $H$ sector rises above steady state. Savers' hours are relatively scarce in the $H$ sector, and the imperfect substitutability of labor inputs precludes firms from equalizing wages across groups.

Third, the housing sector experiences a fall in demand stemming from Borrowers' house downsizing. This reduces housing output, which is shown net of monitoring costs in our graphs. Borrowers need to replenish their housing stock, which contributes to a quick rebound in housing supply. In fact, housing output gross of monitoring costs (not shown in the graphs) increases following the shock. The relative price of houses falls on impact and subsequently rises above steady state. This behavior of the real house price is driven by the dynamics of the real marginal cost in the housing sector, which is an average of Borrowers' (Wage B H) and Savers' (Wage S H) wages in that sector.

Finally, total output in the economy falls, independently of whether housing output is measured net or gross of monitoring costs. $^{12}$ The non-durable sector represents more than 90 percent of the economy, and its dynamics drives that of total output.

\footnotetext{
${ }^{12}$ For consistency, our graphs report total output net of monitoring costs.
} 
Our model generates a 1.2-percentage-point fall in total output from steady state and a small, short-lived reduction in real housing prices following an increase in mortgage risk. Our model underpredicts the decline in GDP and the real housing price observed in the 2007-09 recession. The rapid rebound in housing demand due to the replacement of monitoring costs seems particularly counterfactual. We speculate that adding a housing rental market may improve the fit of our model. We also believe that the credit crunch that followed the liquidity crisis played a quantitatively important role in the recession of 2007-09. Our model, however, has no capital and therefore no financial intermediation in providing capital to firms. Modeling the financial sector and a financial accelerator in loans to firms are indeed interesting extensions of this framework. Nevertheless, our model captures well the transmission of shocks across sectors, as the non-durable sector is significantly affected by a risk shock in the durable one. Indeed, the impulse responses of our model (figure 2) match, at least qualitatively, those of the VAR (figure 1). ${ }^{13}$ As predicted by the model, real consumption, inflation, and the nominal short-term interest rate fall in response to an innovation in serious delinquencies. Interestingly, the model replicates well the hump-shaped response of the real housing price and residential investment to an innovation to delinquencies displayed in the VAR.

\subsection{Low-Leverage Calibration}

Next we analyze how differences in steady-state leverage ratios imply different dynamic responses to a housing investment risk shock. Figure 3 plots the impulse responses of six selected variables to a 40 percent increase relative to its steady-state value in $\sigma_{\omega, t}$ for the low-leverage economy (line with diamonds) and for the benchmark economy (starred line). Figure 7 in appendix 2 plots the responses of a larger set of variables. The effects of an increase in the standard deviation of idiosyncratic risk in housing investment are amplified in the highly leveraged benchmark economy, which is the economy with

\footnotetext{
${ }^{13}$ The VAR evidence is relative to a one-standard-deviation innovation in $\sigma_{\omega}$, while the data reported above is relative to a 40 percent increase in $\sigma_{\omega}$. Moreover, our VAR sample excludes the recent financial crisis.
} 
Vol. 7 No. 1
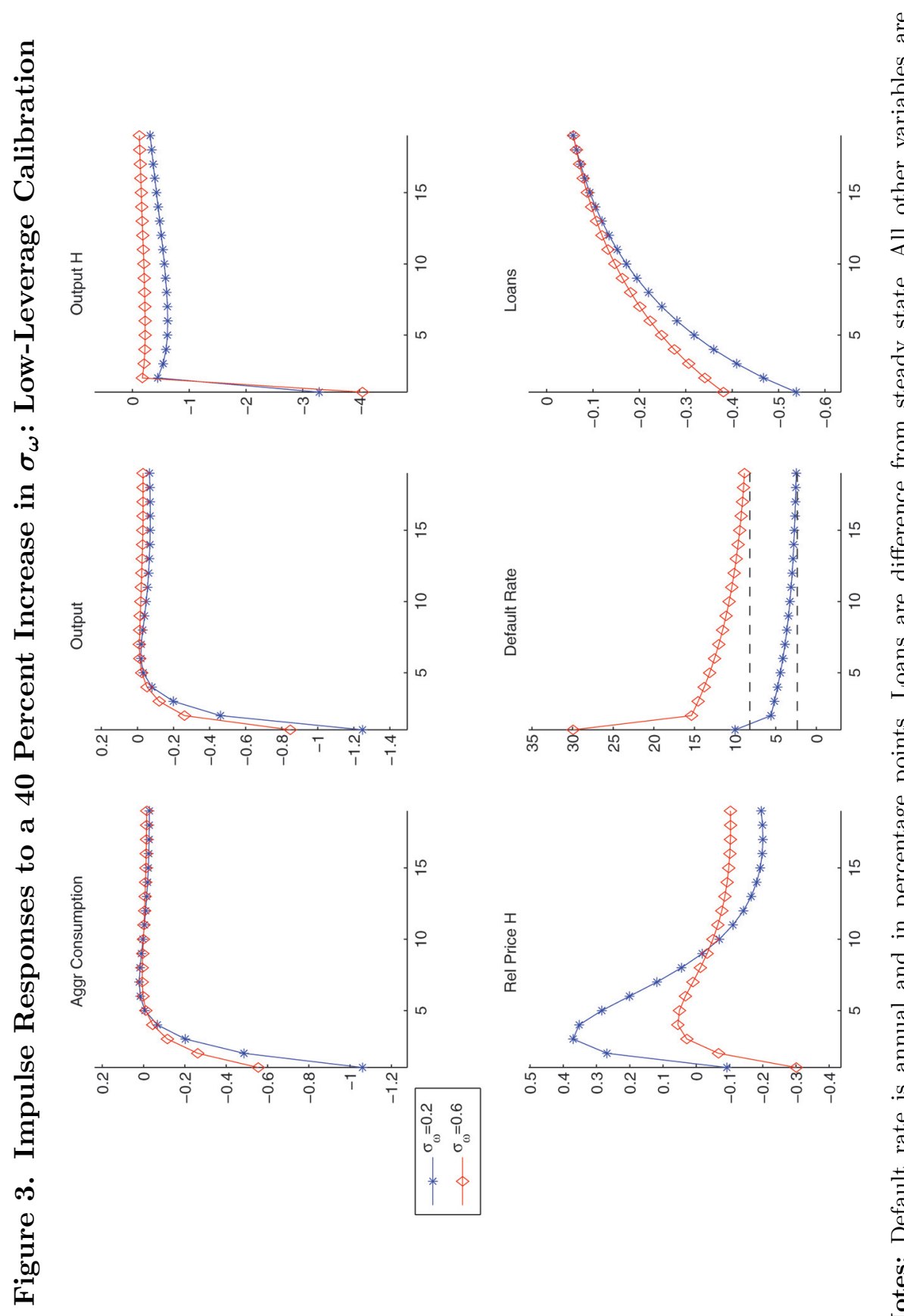

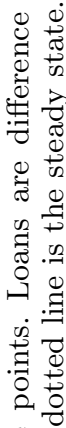

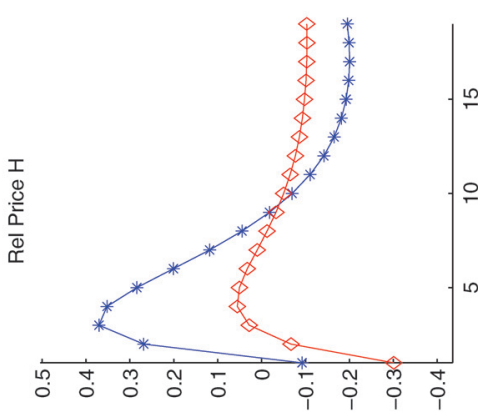

$\infty$

荧

过

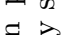

㐘

조 뭉

สี

. .

穿客

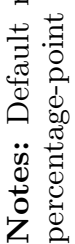


the lower steady-state standard deviation and default rate. In particular, the credit crunch is deeper and the adverse effects on Borrowers stronger. Loans fall more in the benchmark economy, even though the increase in the standard deviation is actually larger in the lowleverage economy. As a result, Borrowers must cut loans, housing demand, and consumption of non-durable goods more in the economy with high leverage. Aggregate consumption and prices of nondurable goods fall more in the high-leverage economy. The deeper contraction in non-durable demand generates a deeper contraction in total output.

\subsection{The Importance of Interest Rate Flexibility}

Our benchmark calibration features a large inertia term in the interest rate rule. Here we analyze the implications of adopting less inertial interest rate rules. ${ }^{14}$ Figure 4 shows the impulse responses of six selected variables to a 40 percent increase relative to its steady-state value in the standard deviation $\sigma_{\omega, t}$, the same shock analyzed in the previous sections, under alternative values for the inertial term in the interest rate rule. The starred line is the benchmark specification where $\phi_{r}=0.9$; the line with diamonds features no interest rate smoothing, $\phi_{r}=0$. For all specifications we keep the coefficient on inflation constant and equal to $\phi_{\pi}=1.5$. Figure 8 in appendix 2 reports the responses of a larger set of variables.

The negative contemporaneous response of the nominal interest rate is dampened down under the inertial interest rate rule. While the interest rate falls less than 60 basis points when $\phi_{r}=0.9$, it falls more than 300 basis points when $\phi_{r}=0$. The different response of the nominal interest rate has important implications for non-durable consumption. Under the inertial interest rate rule, Borrowers cut their non-durable goods consumption more and Savers increase it by less, thereby making the negative response of aggregate consumption stronger. Since the nominal interest rate falls less under the inertial rule, Borrowers experience a smaller reduction in their interest rate payments and a larger increase in real debt via the Fisher effect. This makes them reduce non-durable consumption and raise hours

\footnotetext{
${ }^{14}$ Interest rate rules that respond to output generate similar responses.
} 

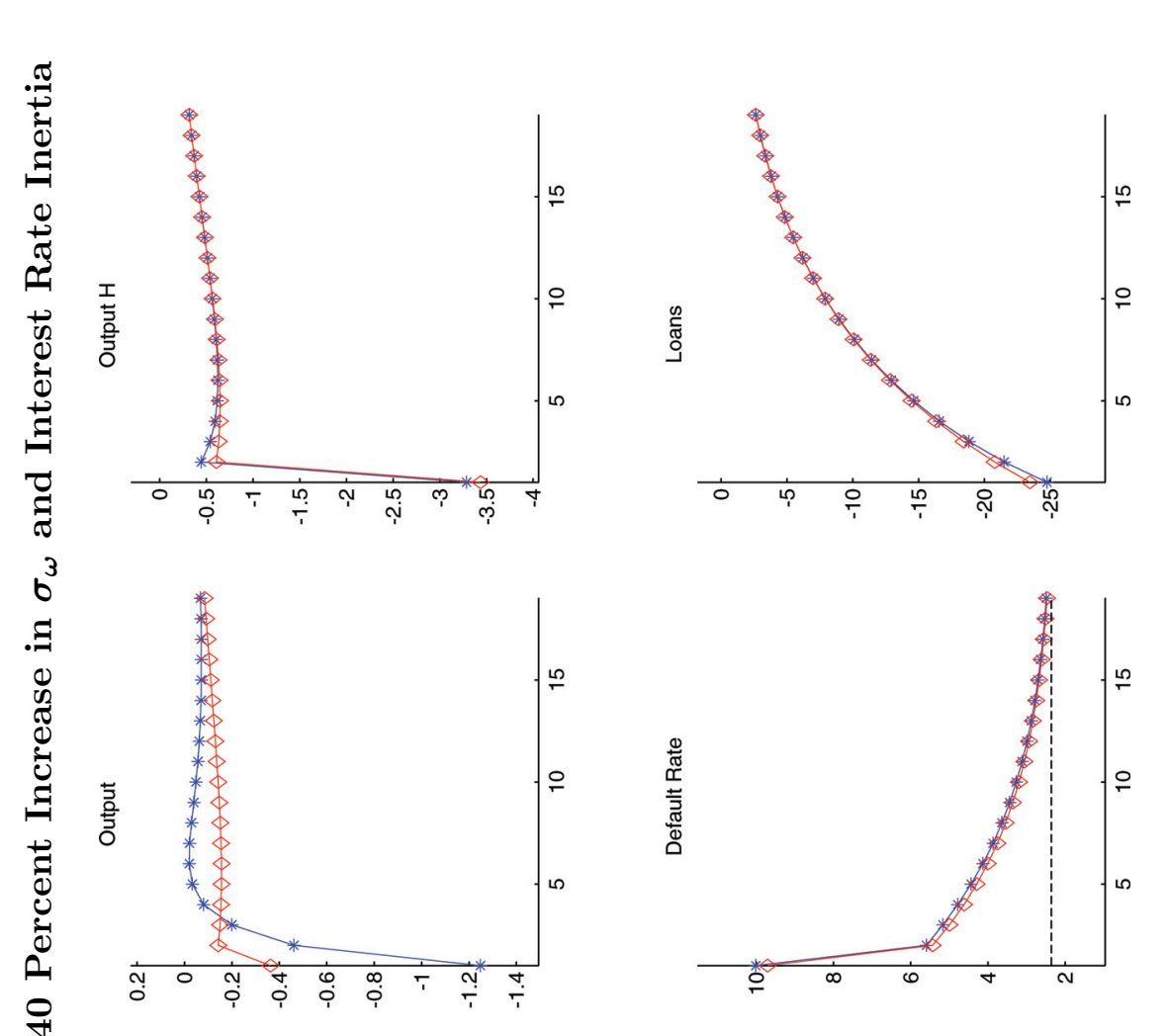

焉 륧 हี 둥 雾

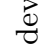

ซ

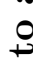
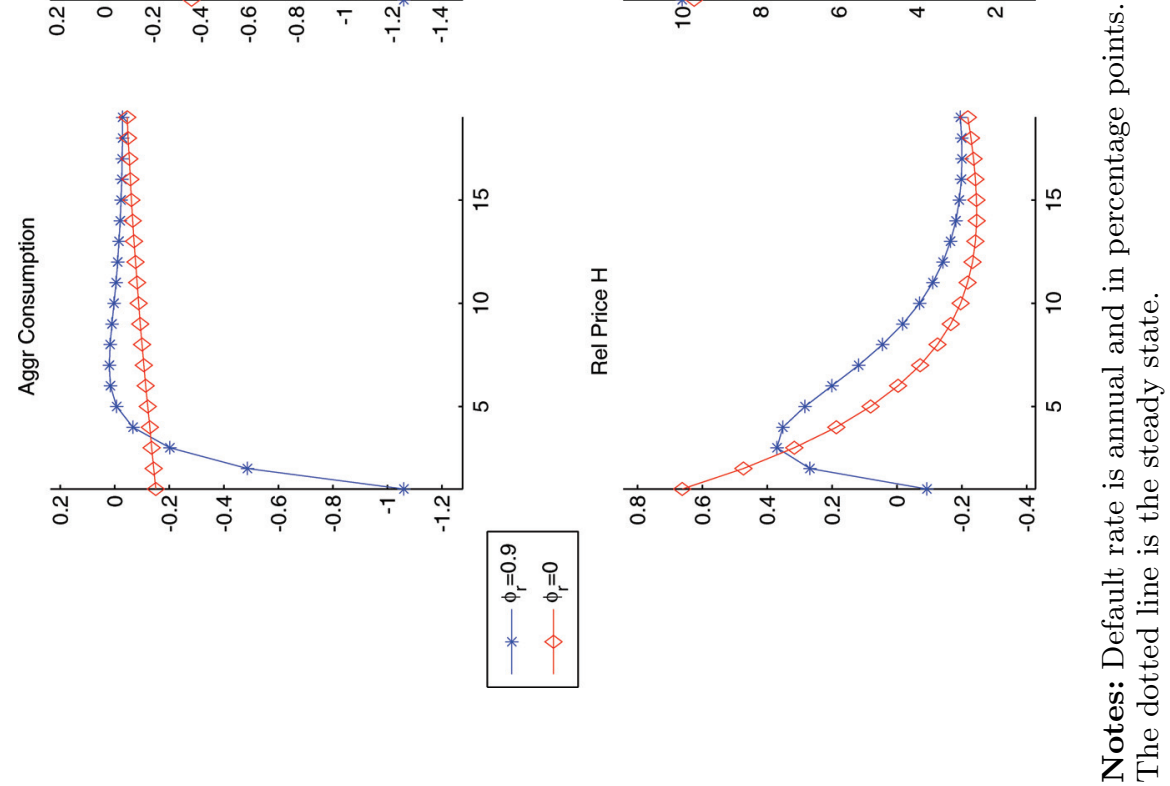

\begin{tabular}{|ll|}
\hline 0 & \\
0 & 0 \\
$\pi^{2}$ & $\Pi_{2}$ \\
$0^{2}$ & $0^{2}$ \\
$*$ & $\phi$ \\
$*$ & $\phi$
\end{tabular} 
worked more, especially in the construction sector. As a result, output in the non-durable sector as well as total output display a deeper contraction under the inertial interest rate rule. Because Borrowers supply more hours in the housing sector when $\phi_{r}$ is high, wages in the housing sector fall more and housing prices are more depressed. Interestingly, housing demand, the default rate, monitoring costs, the external finance premium, the loan-to-value ratio, and loans display almost identical responses under different degrees of interest rate smoothing.

Interest rate rules featuring no inertia display a large degree of interest rate flexibility. The nominal interest rate is cut aggressively in response to an increase in housing investment risk so that the recession in the non-durable sector and in the economy is significantly softened. Notice that strong inertial rules mimic a zerobound scenario where interest rate cannot be lowered further and the negative effects of a risk shock are amplified.

\section{Monetary Policy}

\subsection{Monetary Policy Shock}

Figure 5 illustrates the impulse responses of the model under the benchmark calibration in response to a monetary shock, namely a 25 -basis-point increase in the nominal interest rate $R_{L, t}$. Figure 9 in appendix 2 displays the responses of a larger set of variables. Savers, who are consumption smoothers, reduce consumption of nondurable goods in response to higher interest rates. Borrowers are adversely affected in two ways. First, they experience an increase in the cost of borrowing. Second, deflation in non-durable goods raises their real debt via the Fisher effect. Thus, Borrowers reduce mortgage loans, consumption of non-durable goods, and housing services. The fall in the demand for non-durable goods depresses the real wages in the $C$ sector. Hence, both households increase hours in the $H$ sector, thereby reducing the real wage and the relative price of housing. As real housing prices fall, more Borrower household members default. Technically, $\bar{\omega}_{t+1}$, the threshold value of the idiosyncratic shock below which household members do not repay their mortgages, goes up and with it the default rate and monitoring costs. Since fewer Borrower household members repay their 


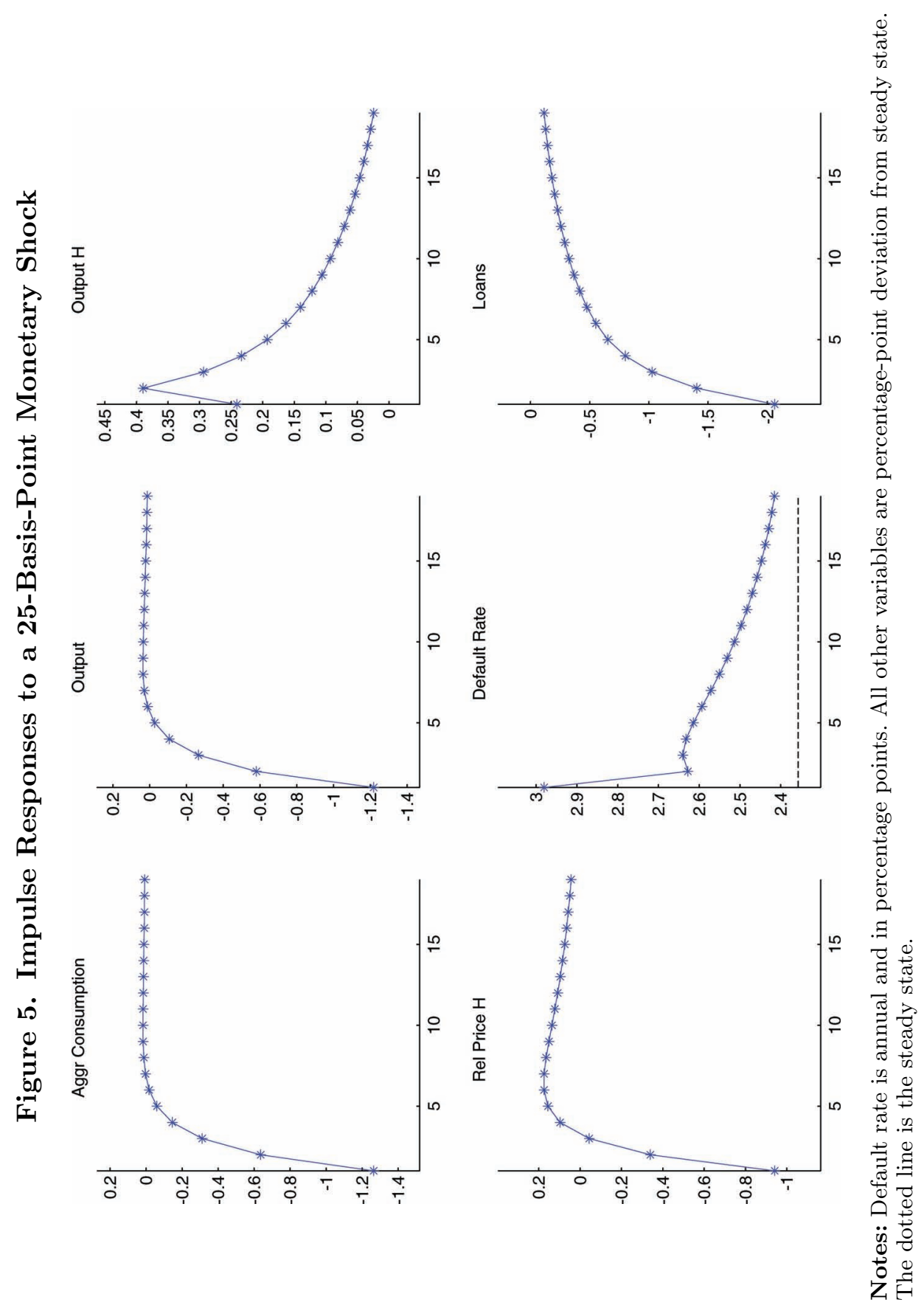


loans, the state-contingent mortgage interest rate rises on impact. The nominal interest rate $R_{L, t}$, which is the risk-free rate guaranteed to Savers on outstanding mortgages to be repaid at time $t$, was set at time $t-1$ and cannot change on impact. As a result, the external financial premium jumps up on impact. The mortgage interest rate increases more than the nominal interest rate, and the external finance premium rises above steady state. The negative wealth effect stemming from higher default, higher mortgage rates, and lower housing value makes Borrowers further cut their consumption of non-durable goods. Aggregate consumption and production of non-durable goods fall. The fall in relative housing prices raises housing demand by Savers, who substitute out of loans into housing. Monitoring costs reduce the existing stock of housing, thereby raising housing demand. Consequently, production in the housing sector increases slightly. Nevertheless, total output falls because the expansion in the construction sector is small and more than compensated by the contraction in the non-durable sector.

A monetary policy shock causes output changes of opposite sign in the two sectors, along the lines of Barsky, House, and Kimball (2007). In their model, a monetary shock that brings down the non-durable sticky-price sector generates an offsetting response in the durable flexible-price sector that leaves GDP unchanged, independently of the relative size of the durable goods sector. Our model shares some features with that of Barsky, House, and Kimball (2007) - in particular, a durable flexible-price sector and a nondurable sticky-price one. The response of our model to a monetary shock displays some similarities to that of Barsky, House, and Kimball (2007). Nevertheless, in our model total output and GDP fall, ${ }^{15}$ independently of whether we measure output in the durable sector net or gross of monitoring costs. Due to imperfect substitutability on both the supply and the demand side, labor does not move across sectors so as to close wage differentials. In addition to that, Borrowers in our model are constrained and fail to behave as consumption smoothers. In particular, Borrower housing demand is driven by the fact that housing can be used as collateral for borrowing,

\footnotetext{
${ }^{15}$ We do not report GDP measured as total output at steady-state relative prices. Nevertheless, GDP would fall in our model.
} 
which makes the shadow value of housing different for Savers and Borrowers.

The result that sectoral output moves in opposite directions in response to a monetary policy shock is at odds with the empirical evidence. Our VAR impulse responses plotted in figure 1 exhibit positive co-movement between consumption and residential investment, confirming the findings of Erceg and Levin (2006). There are two ways to reconcile our model results with this empirical evidence.

The first is to allow for price stickiness in the housing sector. Figure 10 plots the impulse responses of our model for a large set of variables to a 25-basis-point increase in the nominal interest rate under different calibrations. The starred line is the benchmark calibration, where prices in the housing sector are flexible $\left(\theta_{H}=0\right)$. The line with diamonds is the specification with sticky prices in the housing sector $\left(\theta_{H}=0.67\right)$. The line with triangles assumes price stickiness in the housing sector $\left(\theta_{H}=0.67\right)$, perfect substitutability of hours ( $\varsigma=100$ and $\xi=0$ ), and a non-inertial monetary policy rule $\left(\phi_{r}=0, \rho_{m}=0.5\right)$. For all specifications we keep the degree of price stickiness in the non-durable sector constant and equal to $\theta_{C}=0.67$. Under price stickiness in housing prices (line with diamonds), residential investment falls on impact. ${ }^{16}$ When firms in the durable sector cannot fully adjust prices, labor demand contracts more and wages of Borrowers and Savers in that sector fall more relative to the case with flexible housing prices. The drop in labor income and the decrease in the nominal interest rate induce Savers to cut the supply of loans. Borrowers must therefore reduce their debt, and the value of housing as collateral decreases. Thus, the negative income effect stemming from the larger reduction in Borrowers' wages in the $H$ sector translates into a sharper fall in Borrowers' housing demand. This demand contraction explains the decline in output in the $H$ sector. After the first period, however, residential output rises above steady state. This quick rebound is due to both the imperfect

\footnotetext{
${ }^{16}$ For simplicity we report only the cases of $\theta_{H}=0$ and $\theta_{H}=0.67$. Yet, according to our simulations, housing output falls on impact for much lower degrees of stickiness, i.e., for $\theta_{H}$ as low as 0.16 . This result is consistent with the findings of Monacelli (2009).
} 
substitutability of hours and the highly inertial response of the nominal interest rate. Once we relax these assumptions, the recovery of residential investment is much slower (see the line with triangles). Higher substitutability of labor supplies and an aggressive reaction of the nominal interest dampen the wage contraction and the initial drop in housing demand, thereby smoothing the behavior of housing investment.

We speculate that another way to achieve output co-movement in our model is to allow for wage stickiness in both sectors, as suggested by Carlstrom and Fuerst (2006). Wages respond less to a monetary shock in the presence of nominal wage stickiness. As a result, firms face a higher marginal cost and contract more the supply of new houses. This fall in the housing supply may more than compensate for the increase in Savers' housing demand that drives the growth of residential output in our simulations. Whether housing output falls or rises is going to depend on the behavior of relative house prices. We leave the introduction of wage stickiness to future research.

\section{Conclusions}

This paper introduces endogenous default on mortgages in a DGSE model with housing. It analyzes the dynamic response to an increase in the volatility of the distribution of idiosyncratic housing investment risk. We calibrate the size of the shock so as to generate an increase in the default rate of the same magnitude as seen in the data. Under the benchmark calibration, which features an inertial interest rate rule that mimics the zero lower bound, our model predicts a fall in output in both the durable and the non-durable sector. In our model, real GDP per capita falls below steady state by 1.3 percentage points and the housing sector by 3.5 percentage points. In the data, U.S. real GDP per capita fell 3 percentage points below trend in the third quarter of 2009 and residential investment fell almost 17 percentage points. Our model predicts a small reduction in real housing prices followed by a quick rebound. In the data, U.S. real house prices have been below baseline since 2008:Q1 and were 7.3 percentage points below trend at their trough in 2009:Q1. The calibration without inertial monetary policy predicts even smaller 
output reductions, while the relative price of housing increases on impact and falls below steady state five quarters after the shock. We speculate that some features of our model are responsible for underpredicting the drop in housing investment and house prices. We discuss them below.

If we measure output in the housing sector gross of monitoring costs, the housing sector expands following an increase in mortgage risk. This happens because monitoring costs cause a reduction in Borrowers' housing stock that needs to be replenished rapidly. Housing serves as collateral for Borrowers, and housing services enter the utility function directly. It is not surprising that, following a sharp increase in the rate of default on mortgages and sizable losses in their housing stock, Borrowers seek to quickly rebuild their housing stock, thereby sharply raising housing demand. This result is due to our assumption that the monitoring cost is a fraction of the housing stock whose mortgage has been defaulted on. In reality, foreclosure does not cause a reduction of the housing stock, but it represents a loss of revenues by lenders. An assumption closer to reality could model monitoring costs in terms of loans. A model featuring a rental market may also help reduce the strong and counterfactual surge in housing demand by Borrowers, who can get housing services by renting rather than buying houses. In our model, however, Borrowers demand housing not only because it provides services but also because it can be used as collateral. Even though a rental market provides access to housing services without the need to own a house, it is unlikely it will completely eliminate the increase in Borrowers' housing demand.

Our model predicts a rapid rebound in the construction sector following a large increase in mortgage delinquencies. This is not surprising, as housing prices are perfectly flexible and the only friction in our housing sector is imperfect substitutability of labor types. Introducing lags in production or investment adjustment costs in the construction sector would contribute to generate smoother output responses.

In standard DSGE models with non-durable sticky prices and durable flexible prices, a disturbance that generates a recession in the non-durable sector causes an expansion in the durable sector that leaves GDP unchanged. While our model is non-standard in 
a number of ways, our housing sector displays some tendency to move in the opposite direction of the non-durable sector-for example, in response to a monetary policy shock. The VAR evidence at the beginning of the paper shows that the non-durable and housing sectors co-move following both a mortgage risk shock and a monetary shock. Imperfect substitutability of hours in the two sectors brings more sectoral co-movement, as it allows for wage differentials that mitigate the incentive of labor to leave the sector with falling wages to enter the booming sector with rising wages. In fact, an earlier version of our model that did not feature imperfect substitutability of hours displayed a large positive response of the housing sector to an increase in mortgage risk, irrespective of whether output in the sector was measured net or gross of monitoring costs. We speculate, however, that wage stickiness may play an important role in bringing the model closer to reality and dampening out the output response in the $H$ sector.

Our model features financial intermediation and a financial accelerator only for the purpose of housing investment. There is no capital in our simple model and therefore no financial intermediation for providing capital to firms. We believe, however, that a decline in financial intermediation has been a crucial contributor to the Great Recession. In particular, the credit crunch-i.e., the tightening of lending conditions faced by firms - that followed the liquidity crisis reduced economic activity and further amplified the effects of the subprime crisis. Introducing a formal banking sector and financial intermediation to provide capital to firms may help to amplify the output effects of financial shocks like the housing investment risk shock considered here.

The mortgage contract in our model is a one-period adjustablerate mortgage (ARM) contract. Lenders do not take any risk, as they are guaranteed the risk-free rate on the total amount of loans given out to Borrowers. In reality, mortgage contracts are more complex than the contract considered here. In particular, fixed-rate multiyear contracts and ARM contracts with non-standard features may have played a role in setting up the crisis and making it more persistent. At the same time, our mortgage contract is non-recourse, as the Borrower is not personally liable and the lender's recovery is limited to the collateral. Most U.S. states feature non-judicial foreclosure, 
and our assumption describes well this situation. In other states and countries, however, borrowers may be liable for part of the difference between the value of the loan and that of the collateral, as lenders could pursue borrowers' additional assets or require income payments proportional or equal to such difference. The contract featured in our model does not account for these alternative legal arrangements. It could, however, include income payments in addition to the loss of the housing stock. Modeling the possibility to pursue defaulting borrowers' assets in addition to their houses requires the introduction of an asset that borrowers hold in equilibrium. We leave these interesting extensions to future research.

\section{Appendix 1. Data and Sources}

CC: Aggregate consumption. Real personal consumption expenditure (seasonally adjusted, billions of chained 2005 dollars, table 1.1.6), divided by the civilian non-institutional population (CNP16OV, source: Bureau of Labor Statistics). Source: Bureau of Economic Analysis (BEA).

IH: Residential investment. Real private residential fixed investment (seasonally adjusted, billions of chained 2005 dollars, table 1.1.6.), divided by CNP16OV. Source: BEA.

INFLY: Inflation. Percentage change from year ago in the implicit price deflator for the non-farm business sector. Source: Bureau of Labor Statistics (BLS).

RRY: Nominal short-term interest rate. Three-month Treasurybill rate (secondary market rate), expressed in yearly units. (Series ID: H15/RIFSGFSM03_NM). Source: Board of Governors of the Federal Reserve System.

QQ: Real house prices. Census Bureau House Price Index (new one-family houses sold, including value of lot) deflated with the implicit price deflator for the non-farm business sector. Source: Census Bureau, http://www.census.gov/const/price_sold_cust.xls.

DEL: Seriously delinquent mortgages, not seasonally adjusted, percentage of total mortgages. Source: Mortgage Bankers Association, National Delinquency Survey. 


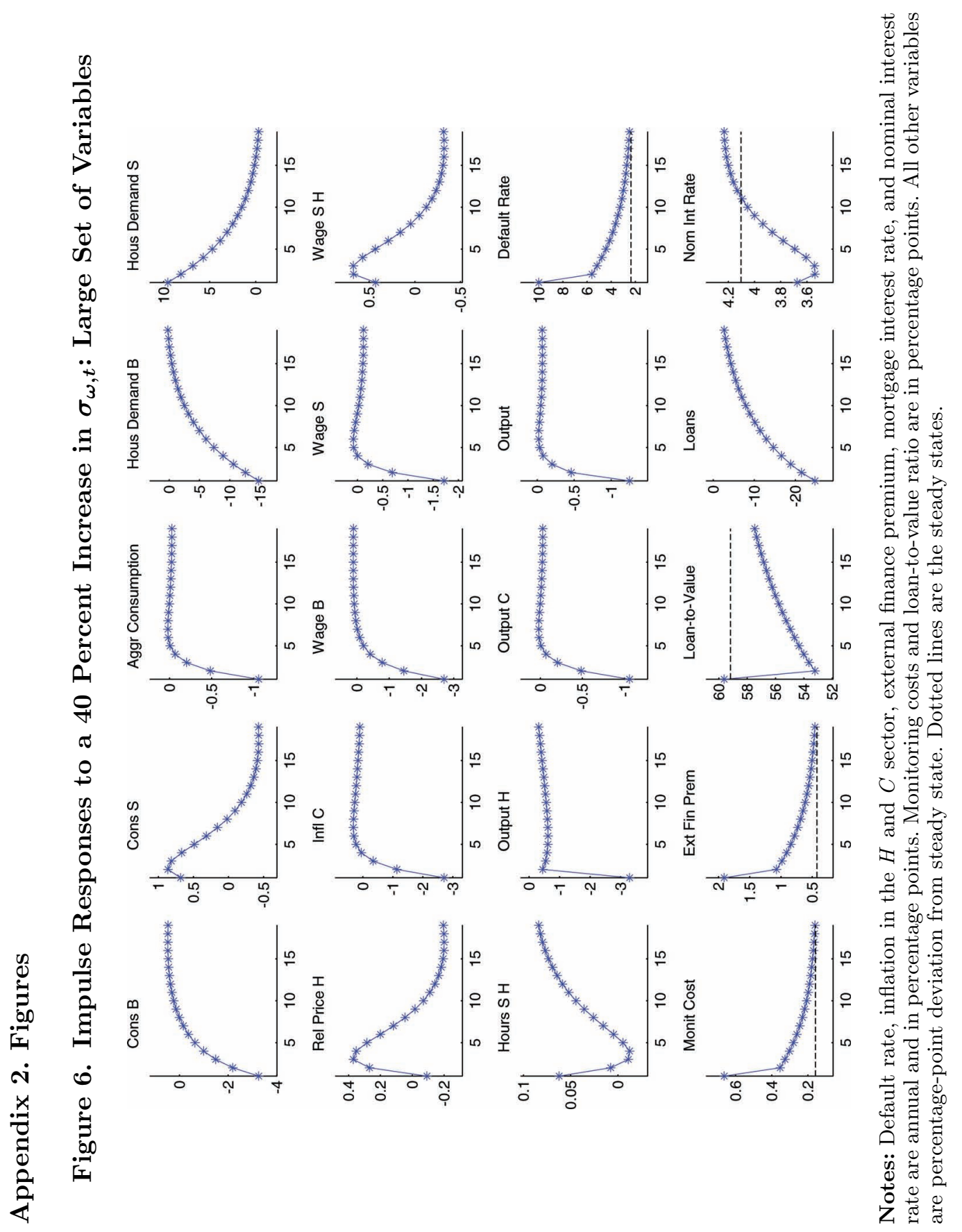




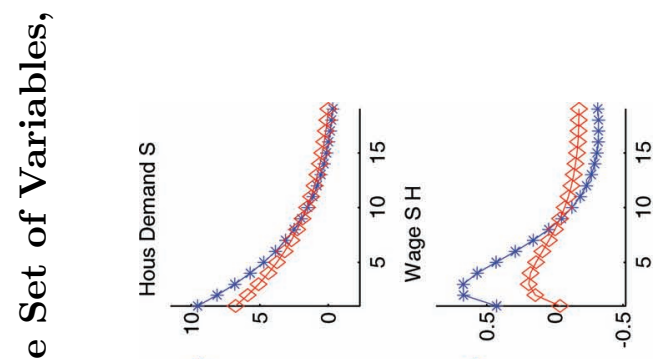

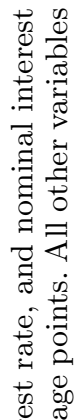
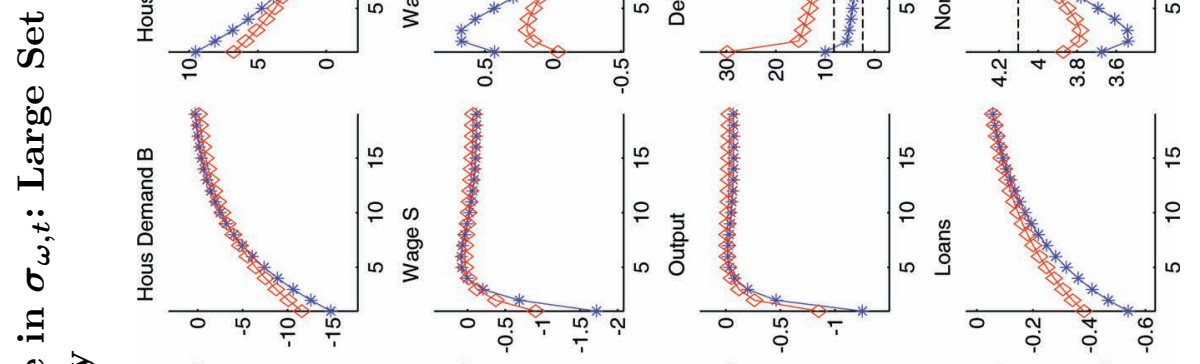

莺

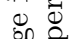

范.

范

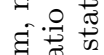
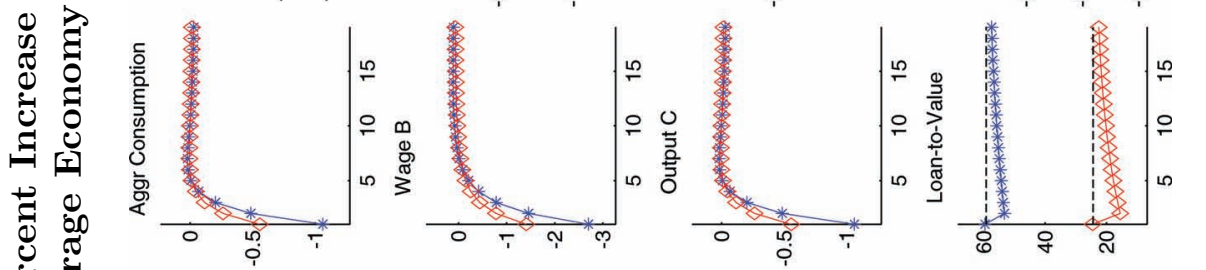

范

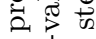

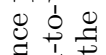

苂 ฮี

สี ซี ซ్ర

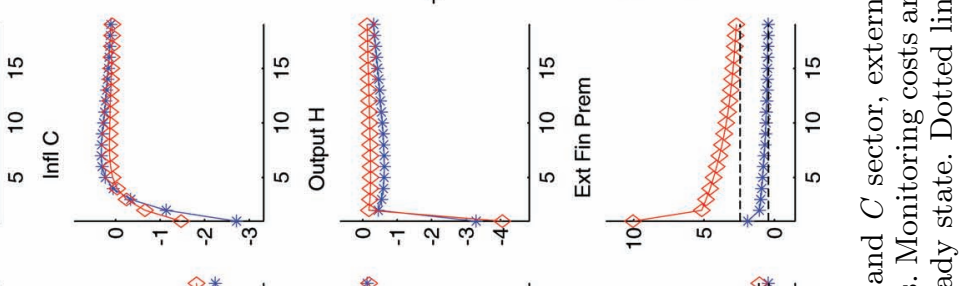

y
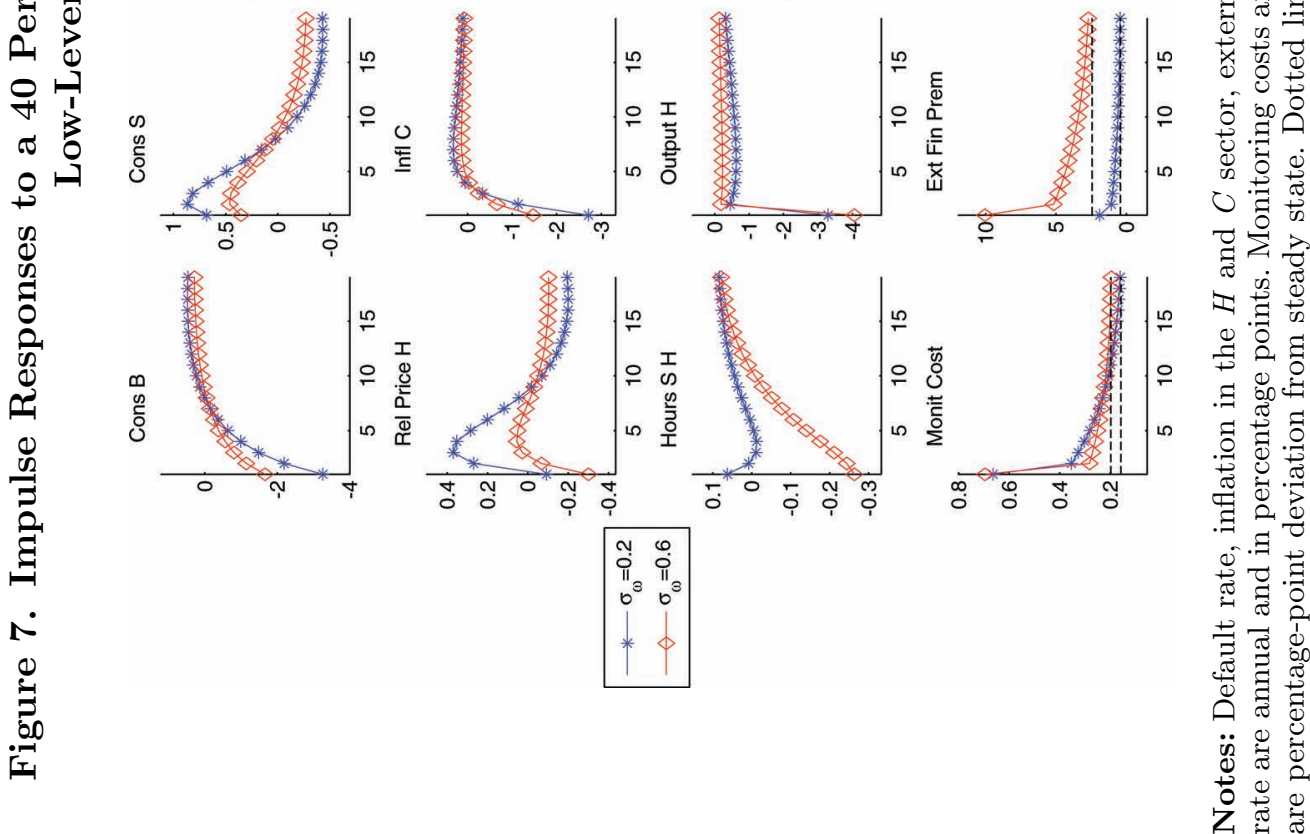


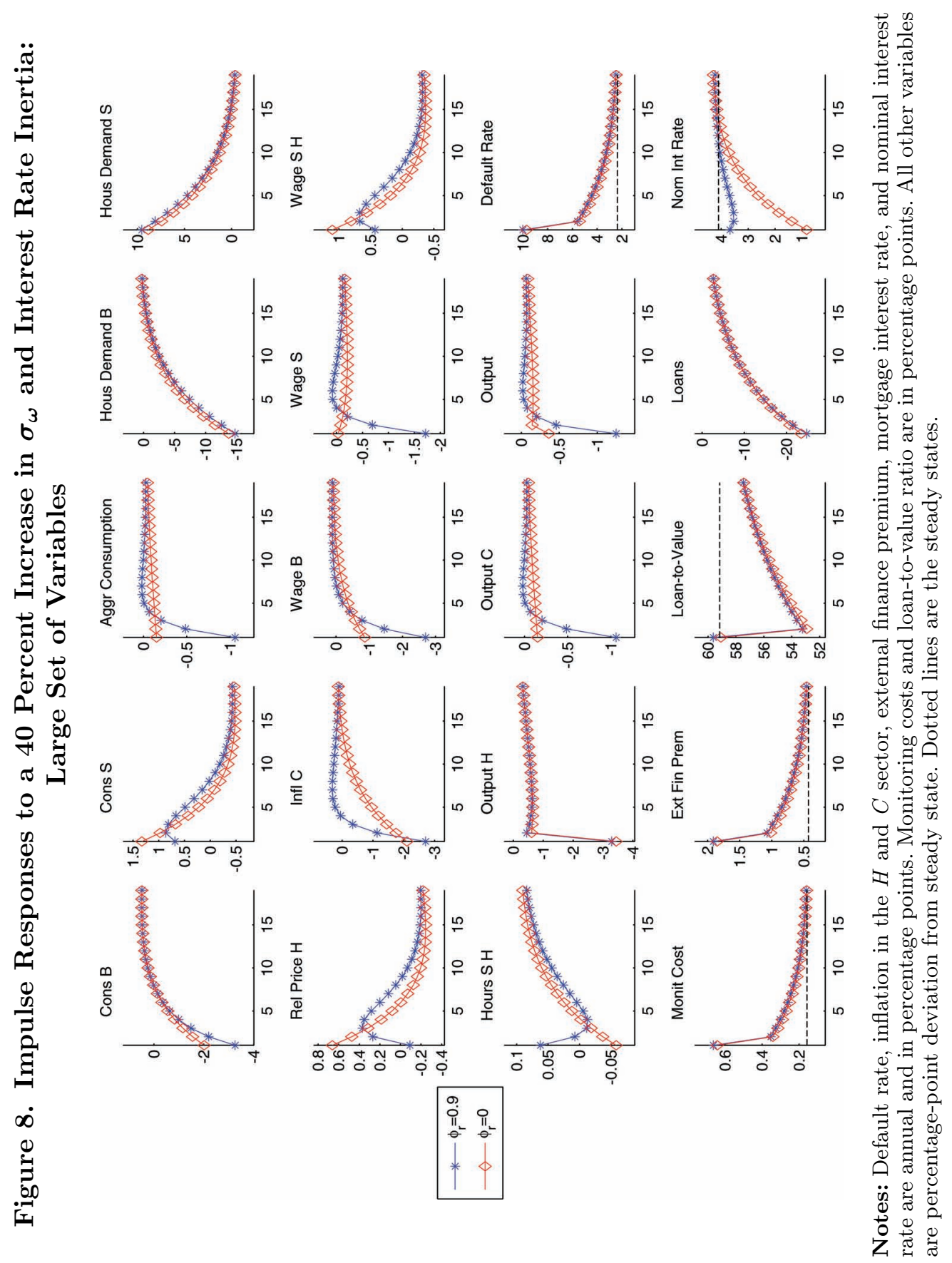




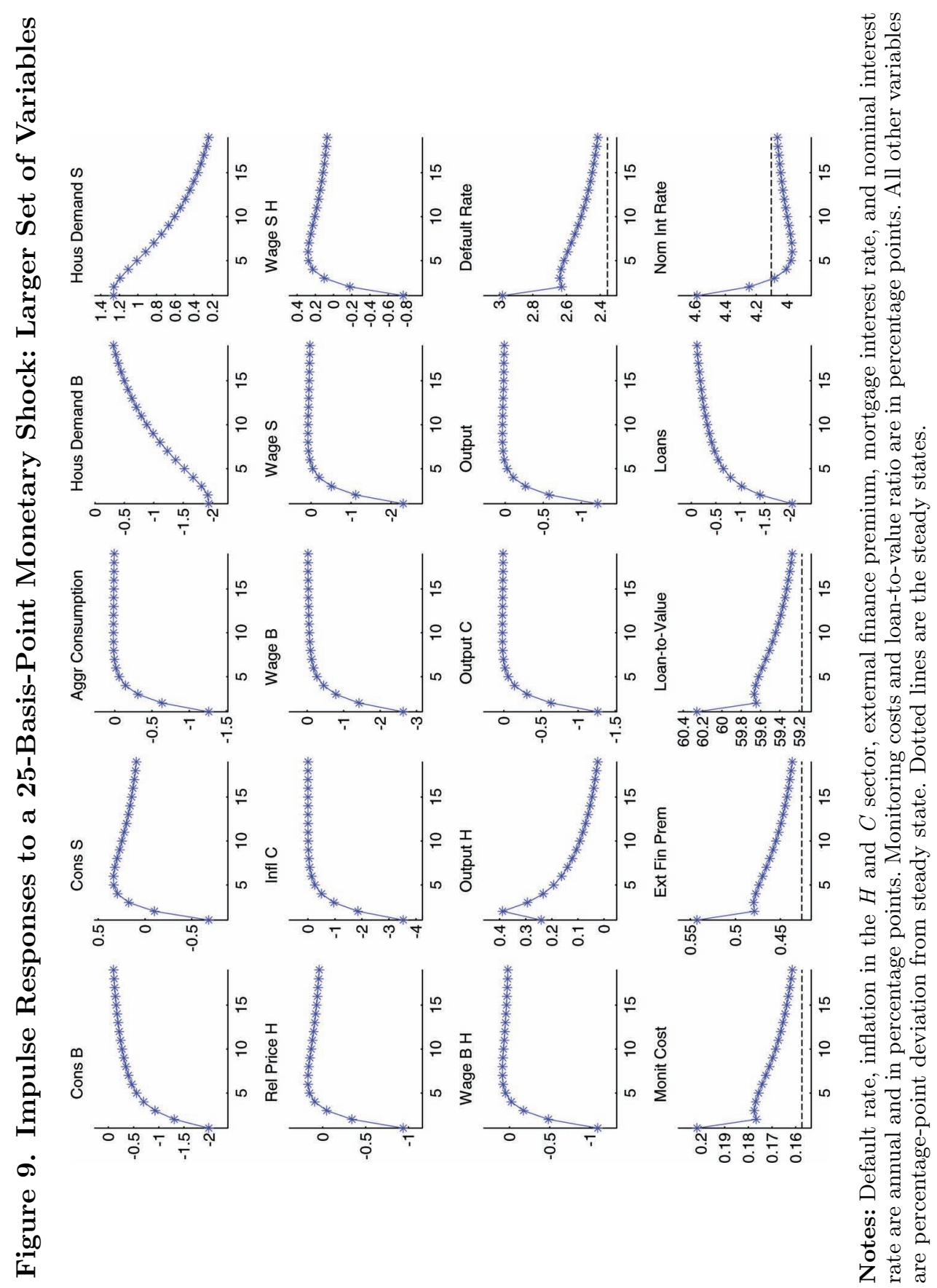




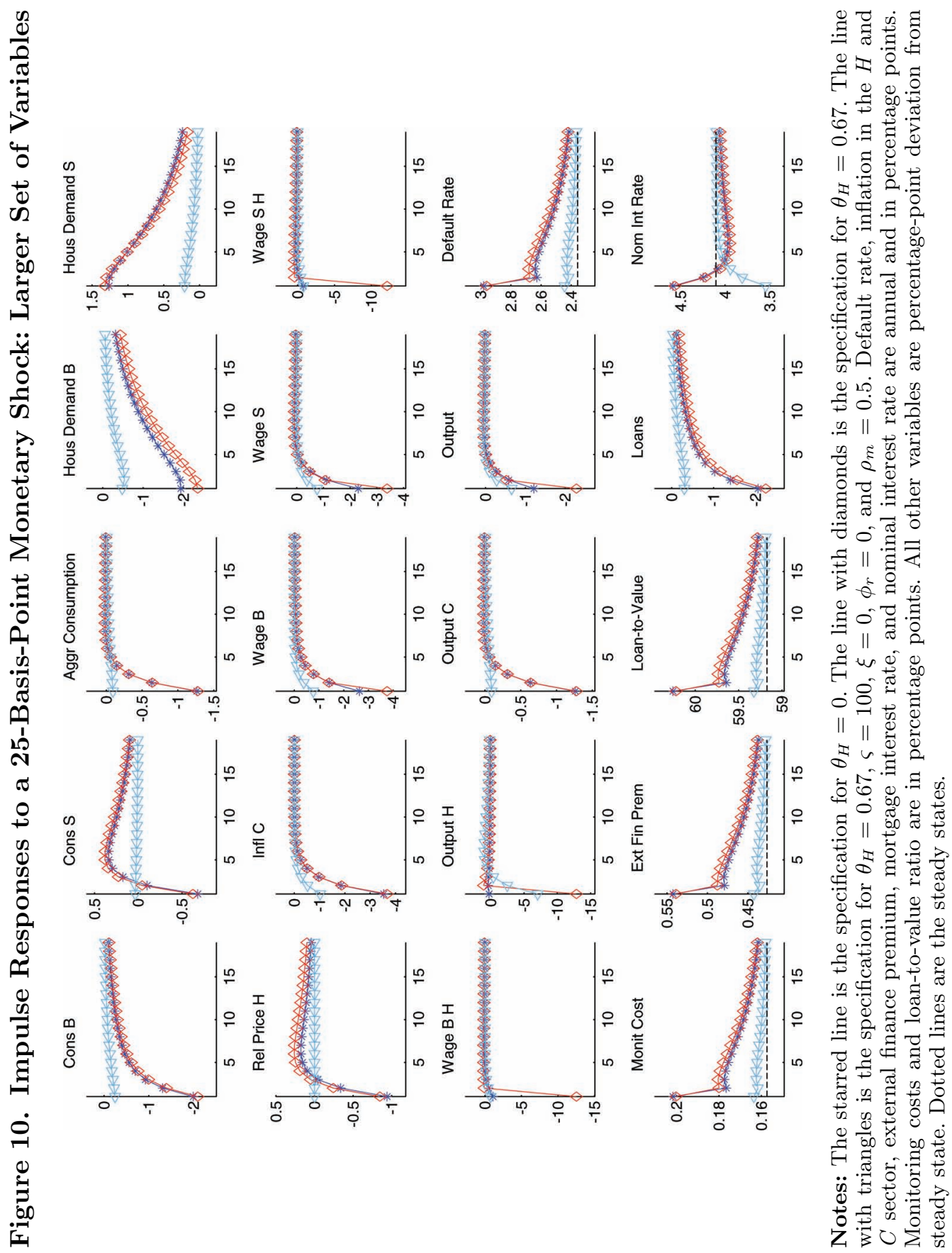


Figure 11. Probability Distribution: An Increase in $\sigma_{\omega, t}$

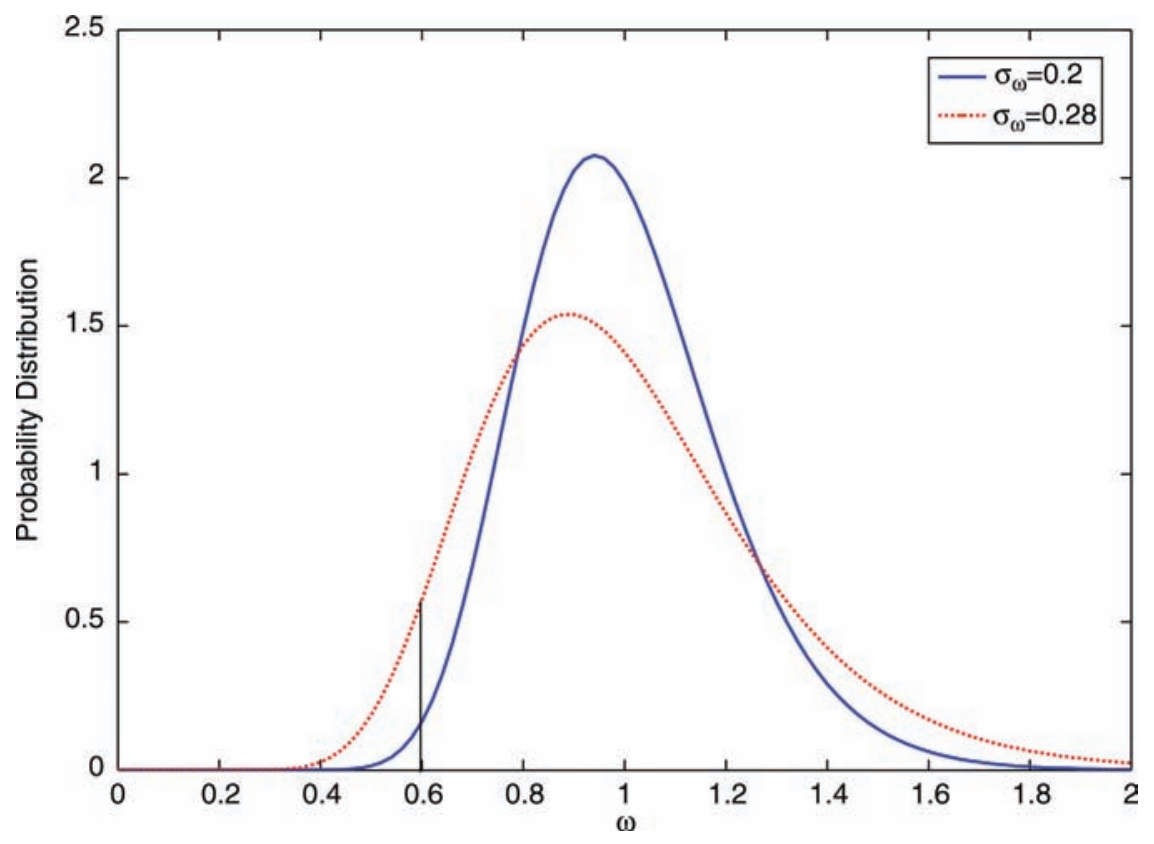




\section{References}

Aoki, K., J. Proudman, and G. Vlieghe. 2004. "House Prices, Consumption, and Monetary Policy: A Financial Accelerator Approach." Journal of Financial Intermediation 13 (4): 414-35.

Barsky, R. B., C. L. House, and M. S. Kimball. 2007. "Sticky-Price Models and Durable Goods." American Economic Review 97 (3): 984-98.

Bernanke, B., M. Gertler, and S. Gilchrist. 1999. "The Financial Accelerator in a Quantitative Business Cycle Framework." In Handbook of Macroeconomics, Vol. 1, ed. J. Taylor and M. Woodford. Amsterdam: North-Holland.

Cagan, C. 2006. "A Ripple, Not a Tidal Wave: Foreclosure Prevalence and Foreclosure Discount." Study by First American Real Estate Solutions (November): 1-17.

Calza, A., T. Monacelli, and L. Stracca. 2009. "Housing Finance and Monetary Policy." ECB Working Paper No. 1069.

Carlstrom, C. T., and T. S. Fuerst. 1997. "Agency Costs, Net Worth, and Business Fluctuations: A Computable General Equilibrium Analysis." American Economic Review 87 (5): 893-910.

—. 2006. "Co-Movement in Sticky Price Models with Durable Goods." Federal Reserve Bank of Cleveland Working Paper No. 06-14.

Christiano, L., R. Motto, and M. Rostagno. 2009. "Financial Factors in Business Cycles." Manuscript.

Cohen-Cole, E., and E. Martinez-Garcia. 2008. "System Risk, Banking Regulation and Optimal Monetary Policy." Manuscript.

Dellas, H., B. Diba, and O. Loisel. 2010. "Optimal Monetary Policy Responses to Financial Shocks." Manuscript.

Erceg, C., and A. Levin. 2006. "Optimal Monetary Policy with Durable Consumption Goods." Journal of Monetary Economics 53 (7): 1341-59.

Faia, E., and T. Monacelli. 2007. "Optimal Interest Rate Rules, Asset Prices, and Credit Frictions." Journal of Economic Dynamics and Control 31 (10): 3228-54.

Horvath, M. 2000. "Sectoral Shocks and Aggregate Fluctuations." Journal of Monetary Economics 45 (1): 69-106. 
Iacoviello, M. 2005. "House Prices, Borrowing Constraints and Monetary Policy in the Business Cycle." American Economic Review 95 (3): 739-64.

- 2010. "Financial Business Cycles." Manuscript.

Iacoviello, M., and S. Neri. 2010. "Housing Market Spillovers: Evidence from an Estimated DSGE Model." American Economic Journal: Macroeconomics 2 (2): 125-64.

Kiyotaki, N., and J. Moore. 1997. "Credit Cycles." Journal of Political Economy 105 (2): 211-48.

Monacelli, T. 2009. "New Keynesian Models, Durable Goods, and Collateral Constraints." Journal of Monetary Economics 56 (2): 242-54.

Townsend, R. 1979. "Optimal Contracts and Competitive Markets with Costly State Verification." Journal of Economic Theory 21 (2): 265-93.

Woodford, M. 2003. Interest and Prices: Foundations of a Theory of Monetary Policy. Princeton, NJ: Princeton University Press. 